London School of Hygiene and Tropical Medicine, MaY 20TH, 1944

\title{
BUDGETARY AND DIETARY SURVEYS OF FAMILIES AND INDIVIDUALS. PART 2
}

\author{
Chairman, Dr. J. Hammond
}

Dr. J. Hammond (School of Agriculture, Cambridge): I would like before we begin the meeting to draw your attention to "Food Consumption Levels", published by the Stationery Office (Special Joint Comnittee Set up by the Combined Food Board, 1944). There is there a passage which is very appropriate today, where it is stated that general food production levels in the United States of America, Canada and the United Kingdom are based on the supplies moving into civilian consumption. The body that drew up this publication makes the remark on page 24: "There is need for adequate dietary survey data as an indication of the relative positions of different occupational, income, regional or other groups of the population". One of its recommendations is that more work should be done, and the meeting today is exactly on this point. I hope contributors' papers, and others, will have some observations which will be very useful to further work.

ReFerence

Special Joint Committee Set up by the Combined Food Board (1944). Food Consumption Levels in the United States, Canada and the United Kingdom. London: H.M.S.O.

\section{Individual Dietary Surveys}

\section{Dr. E. M. Widdowson and Dr. R. A. McCance (Department of Medicine, Cambridge)}

The primary object of all dietary surveys is to discover the amount of food that the individual or the family or other unit chosen for investigation is eating. It is usual, but not necessary, to go on from that to calculate the quantities of proximate principles and other dietary essentials consumed. These manoeuvres may be described as the collection of the data. The secondary object of most dietary surveys may be described as the manipulation of the data, and it usually consists of comparing the results, either with others which have been obtained in a parallel experiment, or with some scale of requirements.

It may be stated fairly confidently that the food intakes of individuals, of families or of institutions may, with a little care, be measured with reasonable accuracy. The method of setting about it naturally varies with the material selected, but in all cases the total food consumed must be weighed. Fewer assumptions have to be made in studying individuals than in studying families. Thus, if any members take meals away from home the amount consumed by them is a matter of guess work, and similar difficulties arise if visitors are entertained during the period of investigation. Allowances may also have to be made for food given to 
domestic animals. Once the total food has been weighed, its composition is usually calculated from food tables, and the accuracy of the result depends upon the choice of the most appropriate food tables for the purpose.

\section{TABLE 1}

Comparison of the Chemical Composition of Mixed Diets as Determined by Direct Analysis with. That Obtained by Calculation from Food Tables

\begin{tabular}{|c|c|c|c|c|c|c|}
\hline Subject & $\begin{array}{l}\text { Method of } \\
\text { determination }\end{array}$ & $\begin{array}{l}\text { Protein } \\
\text { g. per day }\end{array}$ & $\begin{array}{l}\text { Fat } \\
\text { g. per day }\end{array}$ & $\stackrel{\text { Ca }}{\text { g. per day }}$ & $\stackrel{P}{\text { g. per day }}$ & $\underset{\mathrm{mg} \cdot \mathrm{per} \text { day }}{\mathrm{m}}$ \\
\hline \multirow[t]{2}{*}{1} & Analysis & 74 & 117 & $0 \cdot 60$ & 1.09 & $10 \cdot 9$ \\
\hline & Calculation & 76 & 109 & 0.57 & $1 \cdot 13$ & $11 \cdot 3$ \\
\hline \multirow[t]{2}{*}{2} & Analysis & 65 & 141 & 0.62 & $1 \cdot 13$ & $10 \cdot 0$ \\
\hline & Calculation & 71 & 134 & 0.56 & $1 \cdot 10$ & $9 \cdot 0$ \\
\hline \multirow[t]{2}{*}{3} & Analysis & 86 & 120 & 0.63 & $1 \cdot 23$ & $11 \cdot 4$ \\
\hline & Calculation & 76 & 131 & 0.60 & $1 \cdot 21$ & $10 \cdot 4$ \\
\hline \multirow[t]{2}{*}{4} & Analysis & 62 & 120 & $0 \cdot 65$ & 1.02 & $10 \cdot 1$ \\
\hline & Calculation & 62 & 131 & 0.56 & $1 \cdot 03$ & $9 \cdot 3$ \\
\hline \multirow[t]{2}{*}{5} & Analysis & 57 & 100 & 0.82 & 0.97 & $5 \cdot 6$ \\
\hline & Calculation & 60 & 121 & 0.72 & 0.99 & $6 \cdot 3$ \\
\hline \multirow[t]{2}{*}{6} & Analysis & 57 & 91 & $0 \cdot 69$ & 0.90 & $7 \cdot 7$ \\
\hline & Calculation & 51 & 101 & 0.51 & $0 \cdot 79$ & $6 \cdot 5$ \\
\hline Average & $\begin{array}{l}\text { Analysis } \\
\text { Calculation }\end{array}$ & $\begin{array}{l}67 \\
65\end{array}$ & $\begin{array}{l}114 \\
118\end{array}$ & $\begin{array}{l}0.67 \\
0.59\end{array}$ & $\begin{array}{l}1 \cdot 06 \\
1 \cdot\{34\end{array}$ & $\begin{array}{l}9 \cdot 3 \\
8 \cdot 8\end{array}$ \\
\hline
\end{tabular}

Table I shows some results which were obtained on 6 individuals before the war. Composite samples of the diets were analysed and the findings compared with their chemical composition as calculated from food tables (McCance and Widdowson, 1942). The figures calculated for calcium were always lower than the values obtained by analysis because London tap water was used for the cooking, and calculations of the calcium intakes of individuals or of families will always tend to be too low in districts where the water is hard. Contamination of food with iron from kitchen knives and chipped enamel pots and pans will similarly tend to raise the iron intakes above the calculated values (Table 2) (Widdowson and McCance, 1943).

TABLE 2

Varying Degree of Contamination of Apples with Iron from Kitchen UTENSILS

\begin{tabular}{cc|c}
\hline \multicolumn{2}{c|}{ Treatment } & Fe content \\
mg. per lo0g.
\end{tabular}

In the manipulation of the data, if a non-homogeneous group such as a family has been investigated, considerable difficulties at once arise. To average a family's food intake on a per head basis is clearly of little voL. 3,1945$]$ 
scientific value, and there is no way of finding out what proportion of the total each member ate. The convention has been adopted of converting the family intake to the so called man value basis. At least 40 different man value scales have been suggested, and the results of a survey may vary by as much as 30 per cent. according to the scale which is adopted. The individual method of survey is completely free of this objection and, if the individuals have been suitably chosen, the results are ready to be inspected, compared, averaged, and subjected to statistical analysis or compared with theoretical requirements. During the 4 years just before the war we carried out an individual dietary survey on 1000 middle class children living in their own homes, and some of the results illustrate very well how much more can be found out from an individual method than from a family one.

The first thing that an individual survey gives is the variation from one person to another. Table 3 shows the daily calorie intakes of 34 girls

TABLE 3

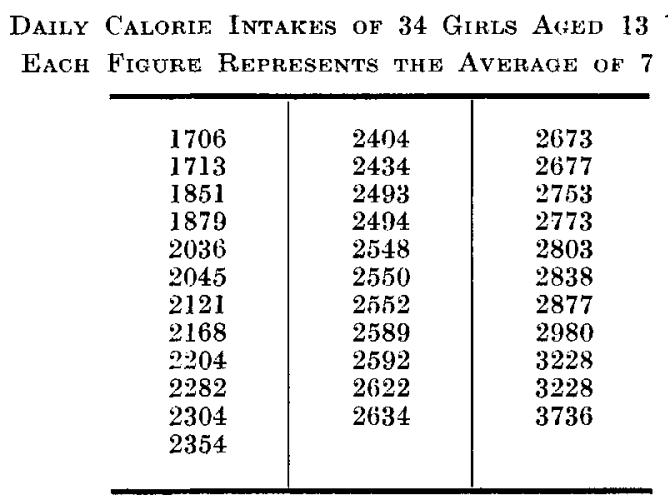

13 years old, and these findings are quite typical. One child was always found to be eating twice as much as another of the same age and sex, and exactly the same thing had previously been shown to be true of adults (Widdowson, 1936; Widdowson and McCance, 1936). All the separate dietary constituents varied just as much or more, and one boy of 2 years ate more than a boy of 17 .

The enormous individual variation from one person to another raises the question of whether one week's diet is representative of a person's food intake over a longer period of time. Would the girl having 1706 Calories a day in one week be having 3736 in the next, for example? This also has been investigated by the individual method. The food of a number of children has been weighed over 4 consecutive weeks, and Figure l shows the daily calorie intakes of a 4 year old girl. The widely fluctuating calorie intakes from one day to another are a well recognized phenomenon, but when the 7 days of each week were averaged the figures for the 4 weeks agreed very closely. It may safely be concluded that, while a week is the shortest time for which a dietary survey should be made, the results for one week are probably fairly representative of the person's accustomed food intake. 
A third point that can be investigated by the individual method is the variation in the intakes of the dietary essentials from one age to another and between the sexes. When the average protein intakes of boys and girls of all ages were surveyed, it was found, as might have been expected, that as they grew older and ate more food they ate more protein, and that the adolescent boys ate more than the girls of corresponding age. The consumption of all dietary constituents did not increase in this way, however. The passage of years made little difference to the calcium intakes of boys, for example, and it brought about a small decline in those of girls. This is because the younger children, although eating less food, drank more milk. There was a similar contrast between vitamins $B_{1}$ and $\mathrm{C}$. Vitamin $\mathrm{B}_{1}$, like protein, is of more general distribution in foods

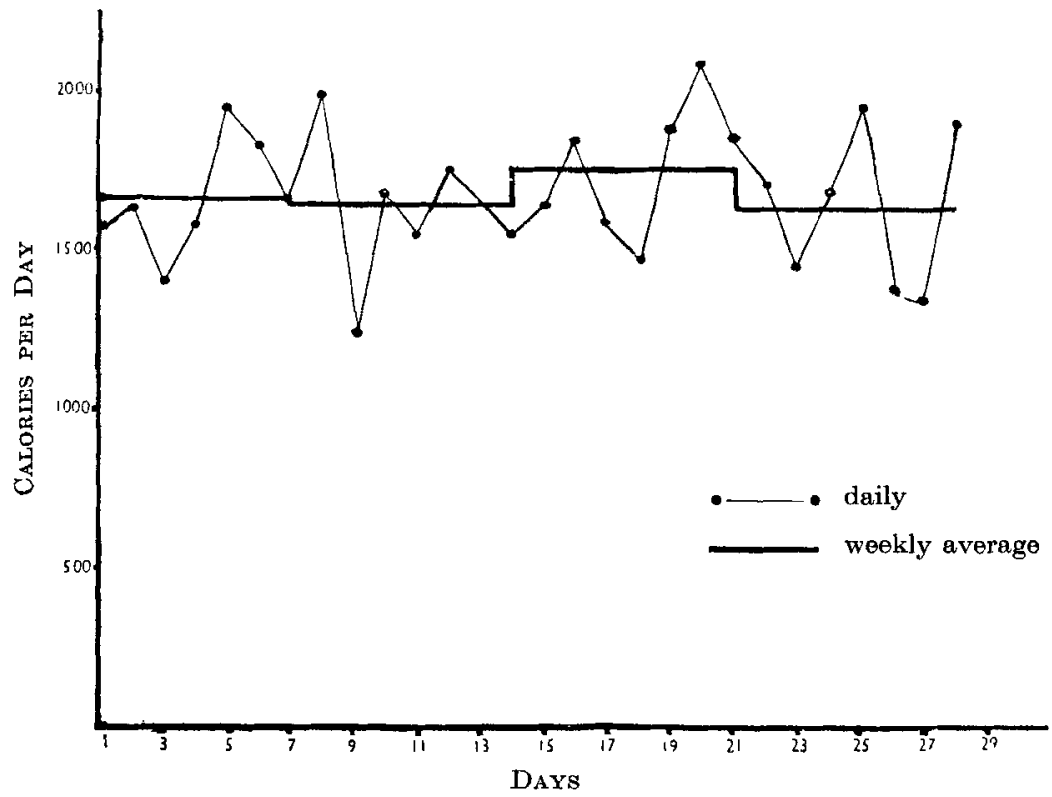

Figure 1. Daily and Wekikty Variations in the Calorif Intake OF A 4 Y Har OLd Girl.

than either calcium or vitamin $\mathrm{C}$, so it tended to increase as the calories increased. Vitamin $\mathrm{C}$ was, before the war, largely obtained from oranges, and the younger children ate more oranges than the older ones.

Not only can the variation in intakes of protein, minerals and vitamins be studied in relation to age and sex, but also the consumption of various foodstuffs, and this is a point about which the person doing family surveys knows nothing. Man value scales may have been devised for calories, protein, calcium and iron, but no one has yet had the temerity to invent one for meat or milk or potatoes. It would be quite erroneous to calculate consumption of these foods on a per head or a calorie man value basis, for they all vary differently with age. It is true that consumption of both meat and potatoes increased with age, but boys of 14 were eating 4 times as much meat as boys of 4 , while they only had $2 \frac{1}{2}$ times as much potatoes.

vor. 3, 1945] 
It is unnecessary to discuss in detail the comparison of individual intakes with scales of requirements, for most of the comments which might be made would apply just as much to the family as to the individual method. It must in the first place be frankly admitted that we do not know what the average, let alone the individual, requirements of any of the dietary constituents may be. Calorie intakes may be a fair measure of calorie requirements, but this is certainly not true of protein or minerals or vitamins. The requirements of calcium, for example, probably vary as much as the intakes of calcium, but there is no reason to suppose that the person who is eating the most needs the most. Protein is usually assigned a "requirement value" of $1 \mathrm{~g}$. per $\mathrm{kg}$. of bodyweight, but there is no ready way of telling whether this is correct or not. Protein requirements are really amino-acid requirements, and should be referred to as such. We cannot yet speak in terms of lysine requirements and methionine requirements, but it is quite time we gave up using terms like lst class and 2nd class protein, which have never had much meaning, and which should never have been applied to the food of people who live on mixed diets and not on purified proteins. Until we know more about this problem we are on dangerous ground in saying that an individual or a family is eating a diet which is inadequate in protein.

No suggestion is made that individual surveys should necessarily replace those on families. Each method has its uses. Individual surveys cannot be carried out on such a large scale as family surveys, and they demand more co-operation on the part of the persons being investigated. They are, therefore, not so suitable for the less educated sections of the population. An individual survey carried out in conjunction with a family survey would be most enlightening. If it is impossible for practical reasons to weigh the food of every individual member of the family at the same time, the father's food in each family might make an interesting study, for this is usually the biggest item in the family diet. Alternatively, the mothers' diets might be investigated; it is usually assumed that they eat $0 \cdot 83$ times as much as their husbands, but a survey along these lines would almost certainly show that this is too high a figure.

\section{ReFerences}

McCance, R. A. and Widdowson, E. M. (1942). Spec. Rep. Ser. med. Res. Coun., Lond., no. 235.

Widdowson, E. M. (1936). J. Hyg., Camb., 36, 269.

Widdowson, E. M. and MeCance, R. A. (1936). J. Hyg., Camb., 36, 293.

Widdowson, E. M. and McCance, R. A. (1943). Lancet, 244, 230.

\section{Discussion}

Professor V. H. Mottram (King's College of Household and Social Science, c/o University College, Leicester), opener: I think that we must congratulate ourselves that one corner of the heavy curtain of silence covering the authors' individual surveys of 1000 middle class children has at last been lifted and that we are allowed to see that the results are as iconclastic with children as they were in 1936 with the famous 63 men and 63 women (Widdowson, 1936; Widdowson and McCance, 1936). One positive and reassuring thing is that a week's survey is long enough, and that a month is not necessary as some of us feared, though there are 
enormous day to day fluctuations. These fluctuations cancel out when a period of 7 days is taken. I have found, however, taking a group of 14 adolescent boys that the day to day fluctuations of intake are within only about 10 per cent. and not 100 per cent. as the authors have found with individual children. There is some small comfort in that.

In the rest of the communication there should be found, however, some cause for heart searching for the conventional dietician. It is emphatically not true that we can estimate within 10 per cent. the individual's intake if we know his age and build and, for the adult, his occupation. Dr. Widdowson and Dr. McCance showed that, at every age in childhood, there was always some child eating twice as much as another of the same age and sex. The findings made with the 63 men and 63 women are thus true of children also. One suspected as much. It is well, though discouraging, to know that this is so. This shows that we must be very chary in using the so called index figure which represents the child's fraction of the needs of an adult male. In fact we ought to discard the index figure altogether and, hence, we must accept the results of diet surveys by the family group method with very great reserve. I know that it is much quicker than the individual method and that therefore we are at times forced to use it, but we have all been warned in the past of quick methods to wrong results.

This work of the authors opens up an avenue of research to discover the reason for these enormous individual variations. If the statement of $\mathrm{Du}$ Bois is accepted that basal metabolism varies only within limits of 10 per cent. on either side of the average (Lusk, 1928), much greater variations in the total metabolism of the people under observation must be due to some physiological peculiarity of their muscular or nervous apparatus. This needs investigation. I fear that we know as yet little about the individual physiology of metabolism and that all this work on the individual method of conducting diet surveys points back to the calorimeter!

\section{REFERENCES}

Lusk, G. (1928). The Science of Nutrition. 4th ed. Philadelphia: W. B. Saunders Co., p. 137.

Widdowson, E. M. (1936). J. Hyg., Camb., 36, 269.

Widdowson, E. M. and McCance, R. A. (1936). J. Hyg., Camb., 36, 293.

Mr. A. L. Bacharach (Glaxo Laboratories, Ltd., Greenford, Middlesex): I wonder whether the admitted bias introduced by the individual survey method because of the selection of those willing and able to co-operate might not introduce an associated bias of dietary habits. A study of intakes is not necessarily informative about requirements unless there is complete freedom of choice. The great range in valorific intakes shown by Dr. Widdowson and Dr. MoCance might reflect psychological factors such as severity of parental control over the eating of sweets as well as more purely physiological ones. Nevertheless, any information that might be obtained about the frequency distribution of intakes and requirements is urgently needed and very much to be welcomed.

Professor J. R. Marrack (London Hospital, Whitechapel, London, E.1): What is Dr. Widdowson's opinion of the validity of figures for made up dishes, because in one institution, I found a 20 per cent. variation in the amount of solids in porridge. Dietary data for individuals should be VoL. 3,1945$]$ 
correlated with other data. It should be possible to get these men and women investigated by an individual method and to see what happens to them. What does a person who eats something over 4000 Calories a day do with them? Dr. Happold has some interesting figures about physical activity which give very valuable information on the subject.

Dr. M. E. Lampard (2 Lexden Road, Colchester): Children have colds frequently and, at the start of the ailment, they eat very little. Have investigators always taken ailments into consideration?

Dr. F. C. Happold (Biochemical Laboratories, the University, Leeds): The figures mentioned by Professor Marrack concern medical students in the University of Leeds. The energy expenditure of 20 women and 29 men was assessed in November and January by keeping a careful record of all their activities, calculating the energy output from available tables and adding it to estimated basal energy requirements. The students assessed their food intake in the November period and measured their intakes by weighing in the January period. The agreement between the energy intake and expenditure was remarkable, as shown by the average figures below:

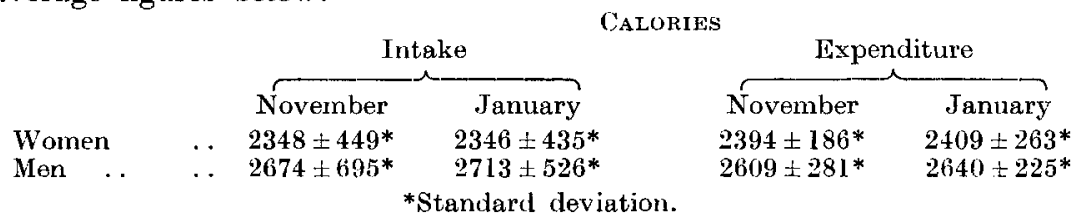

For over two-thirds of the subjects it was within \pm 10 per cent. Changes in bodyweight were observed among the remaining third. The results afford striking evidence of the value of computations based on the tables of McCance and Widdowson (1942).

REFERENCE

MeCance, R. A. and Widdowson, E. M. (1942). Spec. Rep. Ser. med. Res. C'oun., Lond., no. 235.

Dr. Widdowson gave the following replies:

To Mr. Bacharach: In answer to your question about the effect of willingness to co-operate on accuracy of sampling, that might be a serious factor among the less educated sections of the population and therefore with them the individual method is less suitable but, among the classes we were investigating, the so called middle classes, 1 do not think that such a factor comes in nearly so much, because there is no reason why the psychological samples should also be physiological samples.

To Professor Marrack: Made up dishes are a nightmare to the investigator by the individual method and are bound to introduce inaccuracies, but $I$ think that these tend to average out. I agree that an individual child's rice pudding might have been more milky than had been calculated, but we take the average recipe. We frequently write back to the people who have done the food weighing for us to get their own recipes.

To Dr. Lampard: Minor ailments do not make a great deal of difference. As you say, children are always having colds, so it is only fair to take the good with the bad. 


\title{
Survey of Methods Used in Preparing and Cooking Vegetables
}

\author{
Dr. G. Wagner (Wartime Social Survey, Imperial House, Kingsway, \\ London, W.C.2)
}

The purpose of this inquiry, carried out at the request of the Ministry of Health, was to find out how housewives prepare and cook their vegetables; the results were given to the Dunn Nutritional Laboratory in Cambridge, where the vegetables were prepared and cooked in the same way as the housewives had done, and were then analysed chemically for their vitamin content. The results thus obtained could then be applied as a standard when the vitamin intake was calculated from the results of individual dietary surveys; a few additional questions to the housewife as to the preparation and cooking of her vegetables would easily obtain any further necessary information.

The methods used in the preparation and cooking of cabbage, cauliflower, beans, sprouts, leeks, potatoes, carrots, swedes and turnips were investigated. These 8 were selected as those most commonly used. Selection was necessary as a housewife can only be asked a limited number of questions if boredom and unwillingness to co-operate are to be avoided. We had to be especially careful in this investigation about this point as many of the questions had to be repeated for each individual vegetable.

It was thought that the vitamin content of the vegetables as finally served might be influenced by any of the following parts of the processes of preparation and cooking: The extent to which root vegetables were scraped or peeled; the size of the pieces into which the vegetables were cut; the extent to which the outer green leaves of vegetables were used; the length of steeping in water; the amount of water used for cooking; the length of time of cooking; the presence or absence of a lid on the pan; the use of soda; the time interval between cooking and serving and the extent of reheating; finally, the extent to which vegetables were cooked at one time for more than one meal.

The purpose of the inquiry required the result to be representative for the whole of England. A national sample of housewives had, therefore, to be chosen. The inquiry was limited to housewives because the overwhelming majority of the cooked meals eaten is still served in the home; moreover, dietary surveys are usually concerned only with the home diet and, when they include meals eaten in canteens or at school, experience has shown that it is usually fairly easy to obtain samples for chemical analysis.

\section{Scope of Investigation}

Two thousand six hundred interviews were carried out, a number large enough to allow analysis of the material in respect to 5 regions: The North reaching down to Manchester and Liverpool, the Midlands, the East including Norfolk and Suffolk, London, and the South. Analysis was further made in regard to urban and rural areas, and to income groups on the basis of the basic wage rate of the main wage earner. An attempt was made to group housewives according to whether they went out to work or not as it was thought possible that this might considerably voL. 3,1945$]$ 
affect the cooking habits; housewives were grouped also according to age. Incidentally it was hoped to obtain for the Board of Education and the Food Education Department of the Ministry of Food some indication of the success among the different age groups of their campaign for improving methods of cooking.

Thirty trained investigators took part in the investigation. A list of questions was drawn up and used by the interviewer to obtain the information required. The sample of housewives interviewed included women in their homes and women working in factories, mills, offices and shops.

Interviewing for this survey was rather difficult; as stated already, the questions were repetitive and tedium had to be avoided, but it was even more difficult to avoid vagueness in the answers. When visiting houses the investigator found it necessary to go in and ask to see the pan in which the vegetables were cooked, and the extent to which it was filled with water for boiling the different vegetables. Some difficulty was encountered in getting reasonably accurate information as to how long vegetables were cooked and whether or not the lid was used but, by use of a number of devices, the interviewers were, on the whole, able to satisfy themselves of the accuracy of the answers.

\section{Selection of Vegetables}

Before questions were asked as to how each vegetable was prepared it was necessary to find out whether it was served at all in the household. For the purpose of this survey a vegetable was considered to be served if it was cooked at least once a fortnight during the season. The question was divided into two parts: Did you serve the given vegetable regularly as a separate vegetable dish? Did you use the vegetable in stews or any other made up dishes? Table $l$ analyses the answers to the first question.

TABLE 1

Percentage of Housewives in 2576 Homes Serving Regularly the Listed Vegetables

\begin{tabular}{c|c|c|c|c|c|c|c}
\hline Cabbage & $\begin{array}{c}\text { Runner } \\
\text { beans }\end{array}$ & $\begin{array}{c}\text { Cauli- } \\
\text { flower }\end{array}$ & Sprouts & Leeks & Carrots & Turnips & Potatoes \\
\hline 96 & 70 & 87 & 94 & $\mathbf{4 7}$ & 80 & 72 & 100 \\
\hline
\end{tabular}

Less than 1 per cent. did not eat potatoes. Cabbage and sprouts were the only other vegetables eaten by the overwhelming majority. It is interesting to note that 20 per cent. of the housewives did not cook carrots and that half of them did not cook leeks. It must be kept in mind that these figures do not indicate the quantity of the vegetables consumed, which may vary considerably from one household to another.

In answer to the question: "Do you use vegetables in made up dishes?" 68 per cent. said that they used them in stews, and 40 per cent. in other made up dishes including soups.

Grouping of the answers according to income yielded interesting results. Table 2 compares the selection of vegetables made in homes where the main wage earner earned up to $£ 5$ a week with that found in homes where the income exceeded that sum. 
In general, more vegetables were served by housewives in the higher income group with the one exception of cabbage. On the whole, the differences were not great, being marked only in the case of runner beans and leeks. Slightly more of the housewives in the higher income groups used vegetables for made up dishes.

TABLE 2

Percentage of Housewives in 2 Income Groups Serving Regularly the Listed Vegetables

\begin{tabular}{l|c|c|c|c|c|c|c|c}
\hline $\begin{array}{c}\text { Wage rate of } \\
\text { main wage } \\
\text { earner }\end{array}$ & Cabbage & $\begin{array}{c}\text { Runner } \\
\text { beans }\end{array}$ & $\begin{array}{c}\text { Cauli- } \\
\text { flower }\end{array}$ & Sprouts & Leeks & Carrots & Turnips & Potatoes \\
\hline $\begin{array}{c}\text { Up to £5 } \\
\text { weekly }\end{array}$ & 96 & 65 & 85 & 93 & 42 & 79 & 71 & 100 \\
$\begin{array}{c}\text { More than £5 } \\
\text { weekly .. }\end{array}$ & 97 & 86 & 94 & 97 & 60 & 84 & 74 & 100 \\
\hline
\end{tabular}

No difference in the selection of vegetables could be found between the different age groups, or between women going out to work and those not doing so. This same lack of difference was found in other food investigations, such as one on the incidence of baking, where it was discovered that housewives who also worked baked just as much as those who only looked after their homes. It seems that, in spite of having to work, housewives are unwilling to change their cooking habits.

\section{Method of Preparing Vegetables}

Table 3 gives the percentages of housewives who, in preparing carrots and potatoes, peeled them, scraped them, or cooked them in their skins. The percentage of housewives who cooked potatoes in their skins was relatively small; the great majority peeled them, but more housewives, well over half, scraped carrots.

TABLE 3

Percentage of Housewives who Peeled, Scraped, or Cooked in their Skins, Carrots and Potatoes

\begin{tabular}{|c|c|c|c|c|}
\hline \multicolumn{3}{|c|}{ Treatment } & Carrots & Potatoes \\
\hline $\begin{array}{l}\text { Peeling . } \\
\text { Seraping . } \\
\text { Cooking in skin }\end{array}$ & $\begin{array}{l}\cdots \\
\cdots \\
\cdots\end{array}$ & $\begin{array}{l}\cdots \\
\cdots \\
\cdots\end{array}$ & $\begin{array}{r}40 \\
58 \\
2\end{array}$ & $\begin{array}{r}80 \\
3 \\
17\end{array}$ \\
\hline Number of house & wives & . & 2060 & 2576 \\
\hline
\end{tabular}

Answers about the use of the outer leaves of vegetables are analysed in Table 4. More housewives used outer leaves of cauliflowers than of cabbages, but the majority threw away the outer leaves of both vegetables.

A small proportion of housewives cooked cabbage, beans, swedes, turnips and large potatoes whole. The majority cut them up into quarters or smaller pieces. Nearly half of the housewives broke cauliflowers into small pieces, and about the same number cut the stalks of sprouts and sliced leeks.

voL. 3,1945$]$ 
The overwhelming majority of housewives steeped their vegetables in water for less than 2 hours.

TABLE 4

Perchentage of Housewives Using or Discarding the Outer Leaves OF VEGETABLES

\begin{tabular}{|c|c|c|c|}
\hline Treatment & & Cabbage & Cauliflower \\
\hline $\begin{array}{l}\text { Some outer leaves used } \\
\text { Outer leaves discarded }\end{array}$ & $\begin{array}{ll}\cdots & \cdots \\
\cdots & \cdots\end{array}$ & $\begin{array}{l}19 \\
81\end{array}$ & $\begin{array}{l}29 \\
71\end{array}$ \\
\hline Number of housewives & . & 2485 & 2249 \\
\hline
\end{tabular}

Income did not have much influence on the habits. More housewives in the higher, than in the lower, income group scraped carrots and potatoes; more cooked the potatoes in their skins, and more cooked the other vegetables whole.

Rural housewives were more wasteful than urban housewives with the outer leaves of green vegetables, a habit which is to be expected.

\section{Methods of Cooking Vegetables}

In cooking their vegetables the great majority of housewives, well over 90 per cent., boiled them; as an alternative, about 5 or 6 per cent. steamed them.

Well over half of all the housewives cooked their vegetables in so much water that they floated in the pan. The main reasons given for this practice were that it was the custom, that otherwise the pan would burn, and that vegetables cooked in this way had more flavour. Those who cooked in a small amount of water were aware that with this method the nutritive value of the vegetables served is greater.

Only about 10 per cent. of the housewives started their green vegetables cooking in cold water, but more than half started root vegetables in cold water.

About 90 per cent. of the housewives cooked root vegetables with the lid on the pan, but only half of them kept the lid on when cooking green vegetables; the main reason given for these practices was habit.

It was not possible to get accurate answers about the length of time vegetables were cooked, since most housewives did not time their cooking but decided from the appearance whether the vegetable was done or not.

Bicarbonate of soda was used in cooking green vegetables by 60 per cent. of the housewives.

Vegetables had to be warmed up or kept warm by 24 per cent. of the housewives for one or more members of the family, generally workers, who could not fit in with the regular meal hours.

A bout one-fifth of the housewives cooked vegetables for more than one meal at once; in most cases this meant that the vegetables left over from dinner were warmed up for supper, or for the next day's breakfast.

The main differences in cooking habits were again connected with income. More housewives of the higher income group steamed vegetables, or used only a little water when boiling them. They did so because they were more conscious than the poorer housewives of nutritive values. Similar differences in cooking habits between economic groups were found 
also in other food investigations. In the higher income groups more women were prepared to try new or more elaborate methods than in the lower income groups.

Certain regional differences in cooking habits were found but they were not consistent enough to allow of interpretation, and that again was a fact found in many other food investigations. It will need further inquiries, based on larger samples, before anything definite can be said about regional differences in cooking habits.

No age differences were found, a result possibly disappointing to the Board of Education, but the explanation might be that the housewife of over 45, having brought up her family and having a little more time to spare, might be open to new suggestions and prepared to try new things.

As stated already, no differences in cooking habits were found between women going out to work and those with only their household to care for.

This inquiry has already had one practical result. In all our subsequent dietary investigations we have asked the housewife how she cooks her greens, whether she steams or boils them, if, for boiling, she puts them into hot or cold water, and whether soda is used. In accordance with the answer, we assign different values for the vitamin $\mathrm{C}$ content of the food based on the analytical findings of the Dunn Nutritional Laboratory in Cambridge.

\section{Discussion}

Mrs. B. Callow (School of Biochemistry, Cambridge), opener: Ordinary methods of cooking vegetables involve heavy losses of vitamin C. Can these losses be afforded?

The daily allowance of vitamin $\mathrm{C}$ recommended last year by the Hot Springs Conference was $75 \mathrm{mg}$. for men, and $70 \mathrm{mg}$. for women. This year, however, in "Food Consumption Levels," the English and the Canadians have used 70 per cent. of this as a restricted daily allowance for adults, but not for children, and even the Americans have approved this lower standard, though only as a temporary expedient (Special Joint Committee Set up by the Combined Food Board, 1944). If this restricted standard is taken, it is found that the daily allowance for a man is $52.5 \mathrm{mg}$. and for a woman $49 \mathrm{mg}$; that is to say, the allowance for an average adult is about $50 \mathrm{mg}$. When the assessment is weighted to allow for the extra requirements of children, pregnant women, and nursing mothers, the average daily allowance per head of the population of the United Kingdom works out at $57 \mathrm{mg}$. according to the restricted standard, and $71 \mathrm{mg}$, according to the full Hot Springs recommendation.

Our food, before it is cooked, supplies more than this; even since the war, we have had well over the Hot Springs allowance, and about double the restricted standard. Before the war we had an average of $112 \mathrm{mg}$. of vitamin $\mathrm{C}$ per head daily; we had $107 \mathrm{mg}$. in 1940, 102 $\mathrm{mg}$. in 1941, $122 \mathrm{mg}$. in 1942, and $127 \mathrm{mg}$. in 1943 . Canada is far worse off than we are. There the amount of vitamin $\mathrm{C}$ in the uncooked food only just exceeds the restricted standard, and falls short of the full Hot Springs allowance. It is therefore not surprising that scurvy occurs in Canada.

How far are we from the danger line over here? This depends on how much is lost during storage, preparation, and cooking of vegetables. Most of the vitamin $\mathrm{C}$ of our war time diets comes from vegetables. In roL. 3, 1945] 
the United States, potatoes and other vegetables supply only 55 per cent. of the total vitamin $\mathrm{C}$, and in Canada 56 per cent., but in this country they supply no less than 85 per cent. Since cooking losses are far more serious with vegetables than with fruit, it is even more important to cut down these losses here than in the United States or in Canada.

Yet our methods are most wasteful. I met one woman who prepared cabbages for cooking by cutting them into 4 pieces and soaking them for an hour in boiling water, to kill the caterpillars; it is only fair to add that she was not British. Possibly food education may help. Dr. Wagner found that 19 per cent. of housewives boiled potatoes in their skins, and I doubt if as many would have done this before the war. Unfortunately, official recipes are not always designed to protect vitamin C; some of them still include potatoes and green vegetables, twice cooked. I am not sure whether even the conservative method is necessarily safe. I have seen a demonstrator cut a cabbage into 4 pieces, wash it vigorously and slice it, while still dripping wet, into tiny ribbons, half an inch wide and 2 inches long, and then cook it conservatively. I wonder how much of the vitamin $\mathrm{C}$ was left behind on the chopping board.

If we cannot learn to treat our vegetables properly, there is only one thing I can suggest: we must hurry up and win the war, and get some oranges.

\section{REFERENCE}

Special Joint Committee Set up by the Combined Food Board (1944). Food Consumption Levels in the United States, Canada and the United Kingdom. London: H.M.S.O.

Dr. B. S. Platt (Human Nutrition Research Unit, National Hospital, Queen Square, London, W.C.I): I want to correct Mrs. Callow's statement that the Hot Springs Conference made recommendations as to human requirements for nutrients. The Conference simply used the dietary allowances of the U.S.A. National Research Council (1941) to illustrate how a country could set up for itself a target; the Conference deliberately did not attempt to set up world standards for reasons similar to those which have already been referred to by Dr. Widdowson.

It seems to me unfortunate that the Wartime Social Survey did not obtain information on the freshness of green vegetables, one of the most important single factors affecting their nutrient value.

\section{REFERENCE}

U.S.A. National Research Council. Committee on Food and Nutrition (1941). J. Amer. med. Ass. 116, 2601.

Dr. E. R. Bransby (Ministry of Health, Whitehall, London, S.W.1): The survey on cooking habits described by Dr. Wagner was carried out at the request and with the co-operation of the Ministry of Health. Its object was to estimate the average vitamin content of cooked vegetables so that an assessment could be made of the average vitamin intake of the population. The study was concerned mainly with vitamin $\mathrm{C}$, for that nutrient suffers a more serious and variable loss during cooking than any other. Unless allowance is made for such losses erroneous estimates of actual intake will result. From the results of the survey and from data on the degree of cooking loss according to method of cooking, provided by the Dunn Nutritional Laboratory, average vitamin C 
values were calculated for the various cooked vegetables. Actually the values thus calculated proved higher than those found by analysis; probably because insufficient allowance was made for deterioration during marketing, the point made by Dr. Platt. According to Miss Olliver (1943) these losses may be quite serious, especially if the marketing covers several days. The loss of nutrients occurring at various stages of marketing certainly deserves thorough study.

The survey described by Dr. Wagner has been followed by further work on the vitamin $\mathrm{C}$ content of cooked vegetables. With the present trend of nutritional investigation in which the attempt is made to correlate the nutrient intake of individuals with such factors as the level of vitamin $\mathrm{C}$ in the blood plasma, it is important to know if reasonably accurate estimates of the former can be made from food tables. Samples of cooked vegetables have been taken from a number of homes and information on the methods of cooking has been obtained from the housewives. The vitamin $C$ values have been calculated according to the methods of cooking, and compared with the values found by analysis. A preliminary inspection of the results suggests that, for individual samples, there is considerable difference between the two sets of data.

Reference

Olliver, M. (1943). Chem. and Ind. 62, 146.

Dr. L. W. Mapson (Dunn Nutritional Laboratory, Cambridge): What I have to say is mainly in continuation of the last speaker's remark as to the calculation of vitamin $\mathrm{C}$ intake from information about cooking procedure. Harris and Olliver (1943) recently published a paper in which they compared the amount of vitamin $\mathrm{C}$ in a diet determined chemically with that predicted from tables. On the whole there was agreement but it is necessary to be very diffident in making calculations for green vegetables. Here every step of the process of preparation may have an effect. The survey may provide the information as to the amount of water in which a certain amount of cabbage was cooked, but other factors of importance are the size of the saucepan, and the volume of water at the beginning and end of cooking. There is a given amount of vitamin $\mathrm{C}$ in cabbage; there might be 2 housewives starting to cook exactly similar cabbages; they might use the same saucepan and the same amount of water, but one housewife might simmer her vegetable while the other might boil it and, as a result, the amount of vitamin C retained would be different in each case. Some people use bicarbonate of soda in cooking. This entails no loss of vitamin C during actual cooking but, when the eabbage is removed from the water, it depends on the alkalinity of the water how much vitamin $\mathrm{C}$ remains in the cabbage. Tap water, too, varies in composition, and it is very difficult to control this factor.

Mrs. Callow mentioned the shredding of vegetables; with pieces of the size she mentioned, I do not think there would be more than 10 per cent. loss. It is the direction of the cuts as well as the size of the pieces that is important; there is no real damage done if the cabbage is cut in the proper way. No vegetables lose their vitamin content on wilting; cabbages can keep their vitamin $\mathrm{C}$ content for several days.

REFERENCE

Harris, L. J. and Olliver, M. (1943). Lancet, 244, 454. voL. 3,1945$]$ 


\section{Laboratory Assessment of Nutritive Value of Meals} as Eaten

Dr. G. N. Jenkins (St. Bartholomew's Hospital Medical School, c/o Zoological Department, University of Cambridge), Dr. L. W. Mapson (Department of Scientific and Industrial Research, and Dunn Nutritional Laboratory, Cambridge) and Miss M. Olliver (Research Laboratories, Messrs. Chivers and Sons, Ltd., Histon, Cambridge)

It is not possible in the short time alloted for this paper for full analytical details to be given of the methods regarded as satisfactory for laboratory assessment of the nutritive value of meals. It is proposed merely to indicate some of the points of technique which require special attention when analysing meals, and to give an outline of the methods recommended, as an appendix to the paper when published in the Proceedings of The Nutrition Society. The greater part of this paper will, therefore, be devoted not to the analysis, but to the collection and preparation, of the meal samples. Unless sampling is really representative, the analytical results must be considered valueless and may indeed be harmful on account of the misleading conclusions drawn.

\section{Sampling}

\section{Estimation of Vitamin $C$}

All the foods included in the meal should be bulked for estimation of fat, protein, carbohydrate, mineral salts and vitamins except vitamin $\mathrm{C}$. The reason for isolation of the samples in which vitamin $C$ is to be measured is primarily that only by this means can the special precautions essential for the validity of the 2:6-dichlorophenolindophenol method be observed. These precautions require that the introduction of substances which might interfere with the extraction or titration must be avoided and, especially, oxidation of ascorbic acid must be prevented.

Since fruits and vegetables and their products are, with the exception of milk and liver, almost the sole sources of vitamin $\mathrm{C}$ in human diet, it is relatively simple to ensure that samples of all these foods are taken separately from the other constituents of the meal. A complete list of all foods in the meal likely to contain vitamin $\mathrm{C}$ should first be made. This will normally include cooked vegetables, salads, raw or stewed fruits, jams, and soups and gravies if made with vegetable cooking water. Sampling should be made directly from the bulk of material which is being served onto the plates and not from the filled plates, as otherwise there may be difficulty in separating the food to be examined from other foods. In view of the rapid loss of ascorbic acid on keeping foodstuffs hot, sampling should not be carried out until the meal is actually reaching the consumer. Duplication of samples is advocated when possible, and it is frequently advisable to take samples from different boilers or hot plates owing to the great variability which may be found in ascorbic acid content especially in the case of green vegetables.

The procedure recommended is to prepare beforehand a collection of sampling flasks; those of about $100 \mathrm{ml}$. capacity and with wide mouths are found to be very satisfactory. These should be weighed, each with 
a tightly fitting cork, before and after the introduction of about $25 \mathrm{ml}$. of 20 per cent. metaphosphoric acid. Both flask and cork should be clearly marked with corresponding numbers so that inadvertent mixing of stoppers with consequent inaccuracy in weights does not result in the rush of sampling. All flasks should be labelled so that the appropriate details may be noted immediately they are available.

When the food under test is ready, a fairly large representative sample is removed from the container onto a plate, quickly broken with a fork and mixed. Special care must be taken with green vegetables where the vitamin $\mathrm{C}$ content of stalk and leaf is different. A suitable weight of sample can usually be judged by practice, and calculation from published tables giving the approximate vitamin $\mathrm{C}$ content of foods (Olliver, 1943); the sample is introduced into the acid and the contents whirled round to ensure complete mixing of the acid with the sample to prevent oxidation. Special attention should be given to the preliminary breaking down of root vegetables in order that the acid should soak quickly through the tissue. If the ascorbic acid estimation cannot be carried out immediately, the sample should be placed in the dark, in a refrigerator or ice box at $0^{\circ} \mathrm{C}$., but it is preferable that the sample should be extracted and filtered or centrifuged immediately, since the presence of plant tissue appears to accelerate loss of the vitamin on storage (Mapson and Mawson, 1943). Under such conditions, no significant loss of ascorbic acid should occur up to 24 hours' storage, but it is naturally advisable to avoid delay.

\section{Analysis}

On arrival at the laboratory the weight of the sample taken is determined by reweighing the flask, and the ascorbic acid is extracted according to the specified method by grinding with sand, with a pestle and mortar, filtering or centrifuging, and titrating with 2:6-dichlorophenolindophenol (Harris and Olliver, 1942).

Whilst the reliability of the 2:6-dichlorophenolindophenol method can in general be accepted, judgment must be exercised; thus, interference may occur in exceptional cases due to the presence of reducing substances other than ascorbic acid, such as reductones. Highly caramelized foodstuffs such as roast or chipped potatoes, green vegetables which have been cooked with an abnormally large quantity of soda (Allen and Mapson, 1944), malt concentrates and sugar products which have been subjected to heat for extended periods (Wokes, Organ, Duncan and Jacoby, 1943), and some gravies, are probably the only foodstuffs likely to fall into this category. If the antiscorbutic potency, as determined, is suspected of being high for this reason, a method in which allowances are made for these interfering substances should be used, e.g., titration in the presence of formaldehyde (Lugg, 1942; Mapson, 1943; Wokes, Organ and Jacoby, 1943).

\section{Estimation of Nutritive Constituents other than Vitamin C: Carbohydrate, $F$ at, Protein, Mineral Salts and Vitamin $B_{1}$}

When a meal or series of meals is being tested for nutritive constituents other than vitamin C, one of two methods of sampling is usually followed. The easier but less accurate method is to take 3 or 4 helpings voL. 3,1945$]$ 
or platesful of each course served, to collect these together in a large container such as a gallon glass jar, and mix them suitably. The inaccuracy of this procedure lies mainly in the fact that the proportions of individual foodstuffs in an apparently average helping may be quite different from those in a true average helping. In addition, efficient mixing is frequently difficult because of the large bulk of material involved. The more tedious but more accurate method, and one to be strongly advised, is to collect in one container the calculated weight of each foodstuff consumed in a true average meal. This average amount is obtained by dividing by the total number of consumers the total weight of foodstuff actually consumed, that is the total weight served less the amount uneaten. This involves the individual weighing of each foodstuff, and the assistance of a dietician or suitably qualified supervisor is essential. The work entailed is necessarily greater if this procedure is adopted, but the final results are so much more reliable than those obtained by the method of sampling first described that the extra trouble is fully justified.

Individual variation in the choice of foods offered at meals may introduce very great difficulties in sampling. It is generally recognized that as far as possible the menu adopted by the majority of the consumers should be tested, and that individual idiosyncrasies must be dealt with separately. The alternative to this procedure is to analyse every article included in the menu and from this to calculate the amount of nutrient available for each individual. This is, of course, exceedingly laborious and, in most eases, impossible.

\section{Preparation of Samples for Analysis}

Efficient mixing of the sample is essential if the nutritive value of the meal is to be assessed accurately. This is apparent when 6 to $7 \mathrm{~g}$. only of material are taken for estimating the composition of a day's meals weighing about $3 \mathrm{lb}$. Various mills and mincers have been suggested for this purpose, but in our opinion the most satisfactory results are obtained by using the Waring Blendor. This apparatus produces from mixed meals an exceedingly homogeneous mass, and the danger of contamination with iron or other metals is avoided. The wet mixture thus obtained should be analysed at once, primarily on account of the instability of carbohydrate and vitamin $B_{1}$. Drying of the sample is sometimes recommended as the material will then keep indefinitely and can be analysed at leisure. This procedure is, however, tedious, and it is necessary to keep the temperature sufficiently low to avoid decomposition of the sugar. Oven drying at a temperature of about $60^{\circ} \mathrm{C}$. has been used, but the method to be preferred is undoubtedly vacuum ice drying. It is, of course, important after drying to know the loss in weight of the sample so that correction can be made. Estimation of vitamin $B_{1}$ should be carried out on the wet mixture to avoid the possibility of decomposition on drying and, as a precautionary measure, an amount of concentrated hydrochloric acid, which is 2 per cent. of the weight of the sample, should be added, i.e., $1 \mathrm{ml}$. of concentrated hydrochloric acid per $50 \mathrm{~g}$. of sample. This stabilizes the vitamin for at least 2 or 3 days. 
Analysis

In order to confirm the efficiency of mixing it is considered essential that all estimations should be carried out in duplicate.

It has already been stressed that the object of the present communication is not to discuss the detailed technique of the methods used, but some analytical details require special consideration, and these can be briefly indicated.

For the estimation of fat in mixed meals the soxhlet method is usually recommended. In our experience, however, this method frequently yields unreliable results. For instance, the method of preparing the sample, whether with or without sand, and the duration of drying, have been found to affect significantly the percentage of fat extracted. In addition, care has to be taken in the choice of solvent for extraction. On the whole, petroleum ether seems to give more reliable results than diethyl ether; by some workers carbon tetrachloride is considered the most efficient for this purpose (Jany and Morvay, 1939). We have, however, found that the acid hydrolysis method (Nicholls, Colgate, Fraser and Hughes, 1943) is much more satisfactory than the soxhlet method; not only is preliminary drying with its attendant difficulties eliminated, but the method is less tedious. Analysis of artificially prepared mixed meals in which known percentages of fat had been incorporated showed good agreement of the results with theoretical values when the acid hydrolysis method was used.

For estimating protein the main precaution to be taken is to ensure that digestion is complete before distillation. At least 8 hours' digestion should be given after the liquid becomes clear (Chibnall, Rees and Williams, 1943).

It is strongly advised that carbohydrate should be estimated as starch and as sugar and not calculated by difference. However, if calculation has to be adopted, then about 3 per cent. should be allowed for fibre and ash in a normal mixed meal.

It has already been stressed that the laboratory assessment of the nutritional value of a diet can be considered of significance only if the samples taken are really representative of the meals under examination. To obtain a true assessment it is considered equally important that the period covered by sampling and testing should be representative of the diet. For instance, seasonal variation in foodstuffs is so great that daily analysis of the diet over one week cannot possibly be taken as an average for the whole year. Not only is it well known that the vitamin $\mathrm{C}$ content of the diet is dependent upon the seasonal fluctuation, but also replacement of the steamed puddings of winter by the stewed and raw fruit of summer must essentially alter the composition of the diet. Sampling and testing at random over a period is considered preferable to intensive assessment at one period of the year. It is recommended that samples should be taken daily for at least a week at intervals of about 2 months. If the pressure of work becomes too great in the laboratory, 2 or even 3 days' meals can be conveniently bulked for the estimation of all food constituents except vitamin C. It is, however, essential in such cases to keep the samples in the refrigerator and to analyse them as soon as possible owing to the instability of vitamin $B_{1}$ and the risk of fermentation of the sugars.

voL. 3,1945 ] 


\section{Comparison of the Nutritive Values of Meals as Determined by Calcutation and by Laboratory Assessment}

Apart from work on ascorbic acid little has been published to show the relationship between the values obtained in dietary surveys by calculation and by laboratory analysis. The reliability of the predicted values is to a very large extent dependent upon the reliability of the tables used for calculation and upon the availability of detailed information about the recipes and conditions of preparation of the foodstuffs. A survey has recently been carried out on hospital diets by E. M. Widdowson and her colleagues at the Department of Medicine, Cambridge, and by M. Olliver and her associates at the Research Laboratories, Messrs. Chivers and Sons, Ltd., Histon, Cambridge. Some of the unpublished results are given in Tables 1 and 2. The food tables used for determining the calculated

TABLE 1

Average Daily Intake of Nutrients over a Seven Day Period

Comparison between Results Found by ANalysis and those Determined by Calculatgon from Food Tables

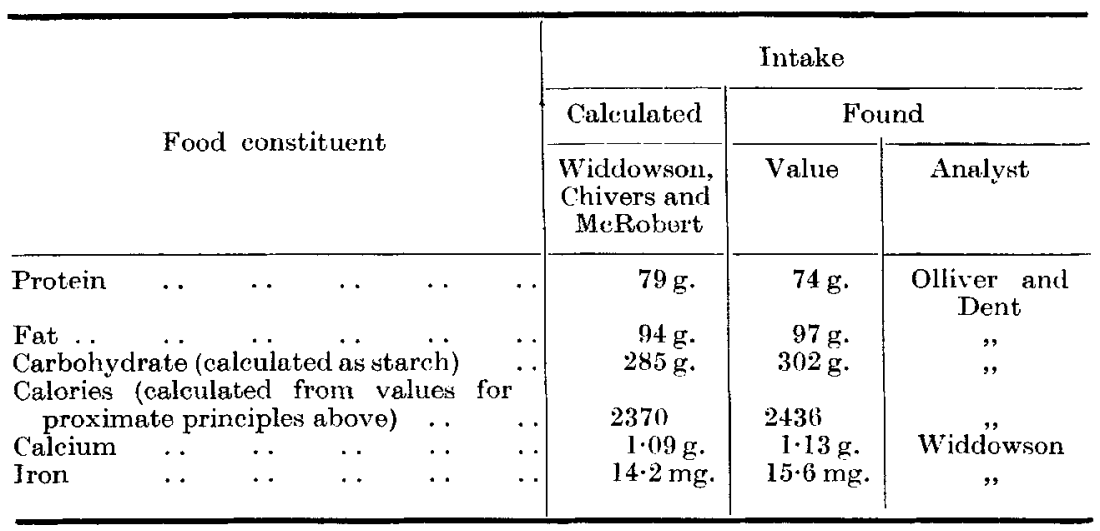

TABLE 2

Average Daily Intake of Vitamin C over a Seven Day Period Comparison between Results Found by Analysis and those Determined by Calculation from Food Tables

\begin{tabular}{|c|c|c|}
\hline \multirow[b]{3}{*}{ Place } & \multicolumn{2}{|c|}{ Intake } \\
\hline & Calculated & Found \\
\hline & $\begin{array}{c}\text { Olliver } \\
\text { mg. }\end{array}$ & $\begin{array}{c}\text { Olliver and } \\
\text { Rowlinson } \\
\text { mg. }\end{array}$ \\
\hline $\begin{array}{ll}\text { Hospital A } \\
\text { Hospital B } \\
\text { Ward } & \mathrm{C} \\
\text { Ward } & \mathrm{D} \\
\text { Ward } & \mathrm{E} \\
\text { Ward } & \text { F }\end{array}$ & $\begin{array}{r}10 \\
12 \\
8 \\
8 \\
6 \\
7\end{array}$ & $\begin{array}{r}11 \\
13 \\
6 \\
5 \\
5 \\
6\end{array}$ \\
\hline
\end{tabular}


values were those of McCance and Widdowson (1940), except in the case of ascorbic acid for which reference was made to values published by Olliver (1943). The agreement obtained can be regarded as very satisfactory, but it should be stressed that in this instance all details of recipes, weights and conditions of preparation were known, close supervision having been exercised by the hospital dieticians throughout the period of test. Unless reliable information of this sort is available, it is considered absolutely imperative to carry out laboratory tests before the diet can be correctly evaluated. Even if reliable data are available for calculation, frequent checking by analysis must be considered essential.

\section{APpendix: Methods}

The following methods are suggested for the estimation of carbohydrate, fat, protein, moisture and vitamin $B_{1}$. That for vitamin $C$ has already been outlined.

1. Carbohydrate. The procedure recommended by McCance, Widdowson and Shackleton (1938) should be followed with a $25 \mathrm{~g}$. sample. We, however, prefer to use two slight modifications of this method:

(a) Sugar. The alcohol extracted sugar is inverted with hydrochloric acid instead of with citric acid as recommended by the authors; $5 \mathrm{ml}$. of concentrated hydrochloric acid is added to $50 \mathrm{ml}$. of thefinal filtrate which is kept at $75^{\circ} \mathrm{C}$. for 10 minutes.

(b) Starch. Instead of treatment with takadiastase, the following procedure, which has been adopted from the A.O.A.C. method (Association of Official Agricultural Chemists, 1940), is used: The alcohol insoluble residue is dried to constant weight at $100^{\circ} \mathrm{C}$., cooled and weighed; 2.5 to $3 \mathrm{~g}$. of this residue are transferred to a fat extraction flask, and heated for 3 hours with $200 \mathrm{ml}$. distilled water and $20 \mathrm{ml}$ concentrated hydrochloric acid under reflux. The contents of the flask are cooled, nearly neutralized with caustic soda, then washed into a $250 \mathrm{ml}$. graduated flask and diluted to the mark. After filtration the solution is titrated with $25 \mathrm{ml}$. standardized Fehling's solution. The percentage dextrose is calculated and multiplied by the factor 0.90 to give the percentage starch.

2. Fat. The method used is essentially that of Nicholls, Colgate, Fraser and Hughes (1943). A suitable weight for the estimation is $2 \mathrm{~g}$. of the sample.

3. Protein. The usual method of digestion with concentrated sulphuric acid in the presence of a catalyst and potassium sulphate is used for the estimation of nitrogen; 6 to $8 \mathrm{~g}$. of sample is a convenient quantity to take for this estimation. After digestion the solution is made alkaline with 1 in 3 caustic soda and then distilled into $50 \mathrm{ml}$. of N/10 sulphuric acid. When no more ammonia is being distilled over, which occurs usually after about $200 \mathrm{ml}$. of distillate have been collected, the excess acid is titrated against $\mathrm{N} / 10$ caustic soda with bromophenol blue as indicator. A control blank test for the complete procedure should also be made.

4. Moisture. Five to $6 \mathrm{~g}$. of the sample are weighed into a moisture dish and mixed with previously dried sand. The dish and contents, including the mixing rod, are weighed and then dried in an oven at voL. 3,1945$]$ 
$100^{\circ} \mathrm{C}$. for 18 hours. After cooling and reweighing the loss in weight and hence the percentage moisture can be determined.

5. Vitamin $B_{1}$. The estimation of vitamin $B_{1}$ is carried out by the thiochrome method (Harris and Wang, 1941; Wang and Harris, 1942).

The contribution made to this paper by Dr. Mapson is based on work carried out for the Food Investigation Board and the Dunn Nutritional Laboratory, and it is published by permission of the Department of Scientific and Industrial Research and the Medical Research Council. Acknowledgment is made also to Messrs. Chivers and Sons, Ltd., for the work carried out by Miss Olliver.

\section{REFERENCES}

Allen, R. J. L. and Mapson, L. W. (1944). J. Soc. chem. Ind. 63, 78.

Association of Official Agricultural Chemists (1940). Official and Tentative. Methods of Analysis. 5th ed. Washington: A.O.A.C. p. 359.

Chibnall, A. C., Rees, M. W. and Williams, E. F. (1943). Biochem. J. 37, 354.

Harris, L. J. and Olliver, M. (1942). Biochem. J. 36, 155.

Harris, L. J. and Wang, Y. L. (1941). Biochem. J. 35, 1050, 1068.

Jany, J. and Morvay, A. (1939). Z. anal. Chem. 116, 166.

Lugg, J. (1942). Aust. J. exp. Biol. med. Sci. 20, 273.

Mapson, L. W. (1943). J. Soc. chem. Ind. 62, 223.

Mapson, L. W. and Mawson, C. A. (1943). Nature, Lond., 151, 222.

McCance, R. A. and Widdowson, E. M. (1940). Spec. Rep. Ser. med. Res. Coun., Lond., no. 235.

MeCance, R. A., Widdowson, E. M. and Shackleton, L. R. B. (1938). Spec. Rep. Ser. med. Res. Coun., Lond., no. 213 , p. 10.

Nicholls, J. R., Colgate, R. T., Fraser, L. S. and Hughes, E. B. (1943). Analyst, 68,48 .

Olliver, M. (1943). J. Soc. chemr. Inw. 62, 146.

Wang, Y. L. and Harris, I. J. (1942), Chem, and Ind. 61, 26.

Wokes, F., Organ, J. G. and Jacoby, F. C. (1943). J. Soc. chem. Ind. 62, 232.

Wokes, F., Organ, J. G., Duncan, J. and Jacoby, F. C. (1943). Biochem.J.37, 695.

\section{Discussion}

Flight Lieutenant S. S. Yudkin, R.A.F.V.R. (R.A.F. Institute of Pathology and Tropical Medicine): The method of direct analysis of food as eaten has been applied to diets of men and women in the R.A.F. Five complete meals as served in the mess are collected at random at each meal during one week. The separate items are weighed and small samples of relevant foodstuffs are taken for immediate estimation of ascorbic acid content. The meals are then all placed in galvanized pails and the whole mixture sent to the Low Temperature Research Station and stored at $-20^{\circ} \mathrm{C}$. Tea and coffee are not collected as liquids, but the required amounts of the dry constituents are added to the pails. A correction is made for food left on the plates by weighing the total amount left by all the people after the meal. At the end of the week the frozen food is ground, mixed and dried in a hot air oven. The food is then finely ground and the resulting powder analysed for various constituents.

The complete results are too complex to be given here and are being published elsewhere, but it is worth pointing out the value of such methods of analysis. By comparing the results obtained in these analyses with results of surveys for signs of deficiency, valuable evidence for the 
adequacy or inadequacy of the supply of various constituents will be available and thus provide evidence concerning the actual requirements of such nutrients. For example, the haemoglobin values of members of the W.A.A.F. on entering the Service and after 6 months show that the iron intake, approximately $38 \mathrm{mg}$. daily, is more than adequate. Similarly, if dark adaptation may be taken as a specific indication of sufficiency or insufficiency of vitamin $A$ in the diet, which is not yet certain, it may be said that the amount of vitamin A in the R.A.F. diets, approximately $1000 \mathrm{I} . \mathrm{U}$. as vitamin $\mathrm{A}$ and $3300 \mu \mathrm{g}$. as $\beta$-carotene, is adequate. It has been shown also, for example, that the biological value of the mixed proteins of the diet, only 40 per cent. of which comes from animal sources, is almost as high as that of milk and that therefore the different proteins supplement each other to a largo degree.

These analyses were made possible only by the co-operation of numerous research workers in many laboratories, who conducted some of the analyses or who lent us storage space and laboratory facilities.

\section{School Diets in Elementary Schools}

Miss E. M. Langley (Board of Education, Belgrave Square, London, S.W.1)

\section{Historical Note}

Like so many social services run by the state the provision of meals to schoolchildren was initiated by voluntary organizations.

In 1862 Victor Hugo started an experiment of giving once a fortnight a dinner of fresh meat with a small glass of wine to 40 of the most necessitous children of Guernsey. The experiment was declared successful and many children suffering from rickets were said to have been cured (Silver, 1864).

In 1864 the Destitute Children's Dinner Society was formed in London in connexion with a ragged school in Westminster and a report written in 1871 on metropolitan soup kitchens states that "The physical benefit of the dinners to children is great but it is not the body only that has benefited. The teachers agree in their opinion that those who are thus fed become more docile and teachable." Legislation for the provision of meals (Provision of Meals Act, 1906) was the direct outcome of a report of an Interdepartmental Committee on Physical Deterioration (1904). The Act gave Education Authorities the power to provide meals for schoolchildren. In the new Bill it is intended that this power should be converted to a duty (England and Wales, 1944).

\section{Earlier School Diets}

A few of the dietaries provided by education authorities undertaking school feeding from the beginning in 1906 followed the dietary standard and food values generally accepted at that time. An example of what was regarded as a good school dietary in 1907 is as follows:

Monday, Wednesday and Friday soup, bread and rice pudding.

Tuesday and Thursday .. hash, bread and rice pudding.

The cost of a meal was about 1 .

With a few exceptions this type of meal persisted and, even as recently as 1938 when an inspection was made of the arrangements of 65 local voL. 3, 1945] 
education authorities, it was found that only a small percentage were giving satisfactory meals. The energy value of the diets ranged from 200 to 600 Calories, and the amount of first class protein and fat from 1 to $10 \mathrm{~g}$. An incident which took place during the inspection serves to illustrate the poor quality of some of the meals served at that time. A canteen was visited on Friday. The woman in charge said: "Oh, if only you had come on Monday!" and, on being asked why she would have preferred Monday, she explained that they had a supply of new bones for the soup every Monday and of course, by Friday, after the bones had been cooked 5 times the liquor had become much less good and consequently the soup was flavourless.

In spite of these unsatisfactory conditions a considerable amount of investigation on suitable dietaries was being done and as an outcome of this work the meal known as the "Oslo breakfast" was evolved (Schiøtz, 1934). This consisted of two-thirds of a pint of milk, $3 \mathrm{oz}$. of brown bread toasted, three-quarters of an oz. of butter, one and a half oz. of cheese, a large helping of a good mixed vegetable salad, and an orange.

This meal was tried by the London County Council and other Local Education Authorities, and was found to be popular with the children, but it was subject to the administrative disadvantage that it took at least half as long again to eat as a hot dinner of 2 courses because there was so much hard food to masticate.

\section{School Diels in War Time}

War brought two important reasons for expanding the school meals service. The first was to ensure that the nutrition of schoolchildren should not be impaired by war time feeding, and the second, to relieve housewives with billeted children of the task of cooking a midday meal.

In the early days of the war the school canteens had to make the best use of the supplies of food available and, when rationing came into force, they received supplies equivalent to those of a category $\mathrm{C}$ or ordinary restaurant. The allowances were insufficient to provide an adequate meal for growing children, and the Ministry of Food was asked to help. The result was most gratifying, as the Ministry asked the Board of Education's technical officers to draw up a dietary which they considered satisfactory for schoolchildren. This work was done; the dietary received the full support of the Ministry of Food's Scientific Advisers and, in November 1941, the Board of Education and the Scottish Education Department were able to announce that for school canteens the allowance of meat and sugar would be doubled and that of preserves nearly doubled and, furthermore, that a special allowance of milk for cooking would be available.

In planning the dietary it was assumed that the energy value of the food required by a healthy elementary schoolchild was about 2500 Calories a day and, therefore, the midday meal, which is the main meal of the day for nearly all children, should have an energy value of about 1000 Calories, and most of the necessary first class protein and of the fat must be obtained in this meal. As a general rule a school diet was calculated to supply senior schoolchildren with an energy value of 1000 Calories, 20 to $25 \mathrm{~g}$. first class protein, $30 \mathrm{~g}$. fat in all its forms, $2450 \mathrm{I}$.U. vitamin A, $230 \mathrm{I} . \mathrm{U}$. vitamin $\mathrm{B}_{1}, 54 \mathrm{mg}$. vitamin $\mathrm{C}, 5.7 \mathrm{mg}$. available iron, and $425 \mathrm{mg}$. calcium. 
A 1000 Calorie meal sounds formidable, but in this case it is not so because so many of the calories are provided by foods which are not bulky. For example, the Ministry of Food has allowed $1 \mathrm{oz}$. dried milk powder for every meal. This alone supplies nearly half the first class protein.

To help cooks to make good use of the special allowances, specimen menus were planned to use approximately the quantities of rationed and unrationed foods available. The menus were a great improvement on those in use before the war, as the following examples show: (1) Roast mutton, baked potatoes, Brussels sprouts, creamed rice and jam; (2) salmon and parsley roll, potatoes, runner beans, summer layer pudding and custard sauce; (3) cheese salad, potatoes, chocolate sponge and custard sauce.

The usual charge for the meal is $5 d$.

There has been some reluctance on the part of the cooks, who were accustomed to such meagre allowances before and in the early years of the war, to use the food available. However, reports made by the Board's Inspectors of Meals show that many authorities are providing the meals stipulated and a large number are well on the way to doing so.

\section{Arrangements for Cooking}

There are two distinct types of kitchen where the meals are cooked, the kitchen in the individual school, and the central kitchen supplying a number of schools. The individual kitchen has the advantage that the meal can be served immediately it is cooked and if good cooking methods are employed the food value should not be impaired. Central kitchens are, however, necessary to meet the tremendous demand which could not be catered for by individual kitchens. This is particularly so in congested urban areas where there is no room on the school site to erect a kitchen.

Since fresh fruit has almost disappeared from the menu the loss of vitamin $\mathrm{C}$ in meals conveyed in containers has been viewed with concern and, in 1942, a circular was issued on the use of raw vegetables (Board of Education, 1942). In addition to the salad meal which usually appears on the menu once a week, Authorities were advised to serve a helping of raw shredded vegetables with the meat course every day.

\section{Statistics}

There has been a great expansion of the School Meals Service during the last 5 years. Just before the war about 250,000 meals daily were being served. In July 1940, the Board of Education called for a large increase, and by October 1941, the daily number of school dinners reached 406,000 .

In October 1941, the President of the Board of Education, the Secretary of State for Scotland, and the Minister of Food made a joint announcement calling for the provision within a year of one million meals daily. The programme was fulfilled well within the allotted time and, by Ootober 1942, one million children were having dinner at school. The present total is a million and a half daily, and the target now being aimed at is more than twice this number.

The number of school canteens now operating is just under 12,000. voc. 3,1945$]$ 
The Value of the Service

There is no doubt that school meals and the supply of cheap milk under the Milk in Schools Scheme have had an enormous influcnce on maintaining the health and physique of schoolchildren in war time. The percentage of elementary schoolchildren taking milk under the Milk in Schools Scheme was 78.3 in February 1944 (Board of Edueation, 1944).

The fact that physique has been well maintained is confirmed by the annual reports of school medical officers from all over the country, and by more detailed investigations on growth rate and nutrition of schoolchildren which have been undertaken by various Government departments.

It is most encouraging that this vast service is quickly becoming an integral part of the school regime. The educational and social advantages, thanks to the help given by the teachers, are almost as great as the nutritional.

\section{REFERENCes}

Board of Education (1942). Circular no. 1594.

Board of Education (1944). Statistics for a Day in February, 1944, of Public Elementary and Secondary School Pupils Receiving School Meals and Milk under the Milk in Schools Scheme in the Area of each Local Edncation Authority in Englarut and Wales. [Cind. 6530]. Loudon: H.M.S.O.

England and Wales (1944). Education Act, 1944, 7 and 8 Geо. 6. Сн.31. Londorı: H.M.S.O.

Interdepartmental Committee on Physical Deterioration (1904). Report, Vol. I. [Cd. 2175]. London: H.M.S.O.

Schiøtz, C. (1934). Hospitalstidende, 77, 1032.

Silver, H. (1864). Punch, 46, 24.

\section{Industrial Canteens}

\section{Dr. M. Pyke (Ministry of Food, Portman Court, Portman Square, London, W.1)}

The planning of industrial meals is an interesting subject for scientific study and a subject in which a great deal still remains to be done. Although today very large numbers of meals are served in factories, there is almost no precise, up to date information about the influence of modern industrial conditions on physiological requirements, nor can the scientific literature provide any guidance on the effect of such factors as, for example, shift work or night work. Even if we leave aside for a moment the question of the daily nutritional requirements of industrial workers and consider only what type of meals can most appropriately be provided in industrial canteens as part of the total diet, we find that little is known of the effect of the frequency of meals on industrial efficiency, or of the most suitable timing for such meals, or of their most desirable nutritional composition to fit them for people engaged on different types of work.

\section{Meals Provided by Industrial Canteens}

The kind of meal most commonly provided by industrial canteens is made up of meat, potatoes and vegetables followed by pudding. The nutritional design behind this selection, where it is planned at all, is based on the assumption that people eat 3 meals a day. This, however, is 
very rarely the case. If a meal is defined as any occasion on which food containing at least 200 Calories is eaten at a single time, it will be found that a few workers eat 4 meals a day, most eat 5 and a very large number eat 6.

Table 1 shows the part played by an industrial canteen in the dietary pattern of women engaged in cotton spinning in a Lancashire mill where about 450 people were employed.

TABLE 1

The Calculated Nutritive Value of the Average Meals Eaten by a Group of 20 Women Working in a LaNCashire CotTon Mill

\begin{tabular}{|c|c|c|c|c|c|c|c|c|c|c|c|}
\hline Meal & Tinse & $\begin{array}{l}\text { Calo- } \\
\text { ries }\end{array}$ & $\begin{array}{c}\text { Pro- } \\
\text { tein } \\
\mathrm{g} .\end{array}$ & Fat & $\begin{array}{c}\text { Cal- } \\
\text { cium } \\
\text { mg. }\end{array}$ & $\begin{array}{l}\text { Iron } \\
\text { Ing. }\end{array}$ & $\begin{array}{l}\text { Vita- } \\
\text { nitin } \\
\text { A } \\
\text { I.U. }\end{array}$ & $\begin{array}{c}\text { Vita- } \\
\text { min } \\
B_{1} \\
\text { mg. }\end{array}$ & $\begin{array}{c}\text { Ribo- } \\
\text { flavin } \\
\text { ing. }\end{array}$ & $\begin{array}{l}\text { Nico- } \\
\text { tinic } \\
\text { acid } \\
\text { lug. }\end{array}$ & $\begin{array}{l}\text { Vita- } \\
\text { nin } \\
\text { C } \\
\text { nig. }\end{array}$ \\
\hline $\begin{array}{l}\text { 1. Breakfast } \\
\text { 2. Works }\end{array}$ & & 280 & 6 & 9 & 120 & 1 & 210 & $0 \cdot 15$ & 0.18 & 0.8 & 0 \\
\hline $\begin{array}{l}\quad \text { breakfast } \\
\text { 3. Dinner } \\
\text { 4. Snack } \\
\text { 5. Tea } \\
\text { 6. Supper } \ldots\end{array}$ & $\begin{array}{r}9 \text { a.m. } \\
12.30 \text { p.m. } \\
3 \text { p.m. } \\
6 \text { p.m. } \\
10 \text { p.m. }\end{array}$ & $\begin{array}{l}360 \\
600 \\
210 \\
780 \\
230\end{array}$ & $\begin{array}{r}10 \\
17 \\
4 \\
20 \\
7\end{array}$ & $\begin{array}{r}10 \\
25 \\
7 \\
32 \\
8\end{array}$ & $\begin{array}{r}180 \\
230 \\
60 \\
210 \\
130\end{array}$ & $\begin{array}{l}1 \\
4 \\
1 \\
3 \\
2\end{array}$ & $\begin{array}{r}220 \\
1160 \\
130 \\
500 \\
160\end{array}$ & $\begin{array}{l}0.24 \\
0.36 \\
0.06 \\
0 \cdot 36 \\
0 \cdot 15\end{array}$ & $\begin{array}{l}0 \cdot 20 \\
0 \cdot 32 \\
0 \cdot 09 \\
0 \cdot 36 \\
0 \cdot 22\end{array}$ & $\begin{array}{l}1-3 \\
3 \cdot 6 \\
0 \cdot 4 \\
3 \cdot 0 \\
1 \cdot 7\end{array}$ & $\begin{array}{r}0 \\
16 \\
1 \\
13 \\
0\end{array}$ \\
\hline $\begin{array}{l}\text { Total daily } \\
\text { consumption }\end{array}$ & & 2460 & 64 & 91 & 930 & 12 & 2380 & $1 \cdot 32$ & $1 \cdot 37$ & $10 \cdot 8$ & 30 \\
\hline
\end{tabular}

The contributions made to this diet by the canteen included the works breakfast at 9 a.m. and dinner for some of the workers at 12.30 p.m.

\section{Variation of Calorific Needs within the Same Industry}

Cotton spinning might be thought to be an occupation demanding comparatively little physical activity. In fact, however, it exemplifies very well the physiological diversity which so often appears whenever industries are studied at all closely. This diversity in physiological demands helps to make the precise planning of industrial meals the complex and difficult matter it is. The women whose diet is shown above were not working very actively. A second group of women, however, in the same factory was engaged on high speed cone winding which demands skill and activity, and their energy consumption was found to be well over 3000 Calories. The most striking contrast, however, was the diet of men engaged in mule spinning. The physique of these men was not, in general, good and many of them were not young. Their work was done in a moist warm atmosphere but its most significant feature was that it demanded their walking backwards and forwards with the machines all day. Their nutrient intake is shown in Table 2.

The surveys of which the results have been shown in Tables 1 and 2 and the studies to be mentioned later were carried out by the technique which recently has probably been used most widely by Wiehl (1942) of the Milbank Memorial Fund. This method depends upon questioning the people to be investigated about everything they have eaten during the previous 24 hours. Whenever an item is mentioned, an equivalent amount made available at the interview is weighed. This method of survey has its drawbacks. Like other methods, it depends in part on the skill of the investigator; it is influenced by the fallibility of memory of the subjects, though such forgetfulness and inaccuracy are minimized voL. 3, 1945] 
TABLE 2

The Calculated Nutritive Value of the Average Meals Eaten by a Group of 10 Men Mule Spinning in a Lancashire Cotton Miel

\begin{tabular}{|c|c|c|c|c|c|c|c|c|c|c|c|}
\hline Meal & Time & $\begin{array}{l}\text { Calo- } \\
\text { ries }\end{array}$ & $\begin{array}{l}\text { Pro- } \\
\text { tein } \\
\mathrm{g} .\end{array}$ & $\begin{array}{l}\text { Fat } \\
\text { g. }\end{array}$ & $\begin{array}{l}\text { Cal- } \\
\text { cillm } \\
\text { mig. }\end{array}$ & $\begin{array}{l}\text { Iron } \\
\text { mg. }\end{array}$ & $\begin{array}{l}\text { vita- } \\
\text { min } \\
\text { A } \\
\text { I.U. }\end{array}$ & $\begin{array}{c}\text { Vita- } \\
\text { min } \\
B_{1} \\
\text { mg. }\end{array}$ & $\begin{array}{l}\text { Ribo- } \\
\text { flavin } \\
\text { mg. }\end{array}$ & $\begin{array}{l}\text { Nico- } \\
\text { tinic } \\
\text { acid } \\
\text { mg. }\end{array}$ & $\underset{\substack{\text { Vita- } \\
\text { min } \\
\text { mg. }}}{ }$ \\
\hline Breakfast & & 480 & 13 & 19 & 220 & 2 & 430 & 0.24 & $0 \cdot 28$ & $1 \cdot 4$ & 0 \\
\hline $\begin{array}{l}\text { 3. Dineakfast } \\
\text { 3. Snack } \\
\text { 4. Sea } \\
\text { 5. Tea } \\
\text { 6. Supper }\end{array}$ & $\begin{array}{r}8.30 \text { a.m. } \\
12.15 \text { p.m. } \\
3 \text { p.m. } \\
6 \text { p.m. } \\
10 \text { p.m. }\end{array}$ & $\begin{array}{r}550 \\
860 \\
280 \\
1250 \\
610\end{array}$ & $\begin{array}{r}14 \\
20 \\
6 \\
33 \\
7\end{array}$ & $\begin{array}{l}16 \\
37 \\
12 \\
53 \\
11\end{array}$ & $\begin{array}{r}160 \\
260 \\
70 \\
360 \\
130\end{array}$ & $\begin{array}{l}2 \\
4 \\
1 \\
6 \\
1\end{array}$ & $\begin{array}{l}350 \\
680 \\
70 \\
760 \\
120\end{array}$ & $\begin{array}{l}0.33 \\
0.42 \\
0.06 \\
0 \cdot 66 \\
0.12\end{array}$ & $\begin{array}{l}0 \cdot 24 \\
0 \cdot 39 \\
0 \cdot 09 \\
0.57 \\
0.36\end{array}$ & $\begin{array}{l}1 \cdot 9 \\
4 \cdot 1 \\
0 \cdot 3 \\
5 \cdot 2 \\
4 \cdot 6\end{array}$ & $\begin{array}{r}0 \\
11 \\
0 \\
14 \\
3\end{array}$ \\
\hline $\begin{array}{l}\text { Total daily } \\
\text { consumpition }\end{array}$ & & 4030 & 93 & 148 & 1200 & 16 & 2410 & 1.83 & 1.93 & $17 \cdot 5$ & 31 \\
\hline
\end{tabular}

by rigid restriction of the period of survey to the preceding 24 hours only. The method, however, has many advantages when applied to elucidation of the dietary patterns in industrial feeding. For example, it can be applied directly to a group working on a selected shift or on a single factory process; it occupies only 10 minutes of each subject's time, so that co-operation has little chance to flag; the trouble to each individual is so slight that there is small temptation to change the diet merely to ease the burden of survey. The budgetary survey and the method of individual weighings are never under the complete control of the investigator but, although the present method allows for the weighing only of a replica of the food eaten and not of the actual food eaten, it is at least wholly under control and can be applied directly to those individuals whom it is desired to study. The nutritional value of that part of the diet obtained from the canteen can, of course, be assessed by direct weighing followed by calculation or, if necessary, by analysis.

Table 3 shows the composition of the full hot meal offered by the canteen to the people in the cotton mill whether their Calorie needs were 2500 or 4000 . In the same table is shown the composition of the average meal actually chosen by 5 out of a group of 10 women working on a single process. These figures are compared again with the nutritive value of the average meals eaten at home by the other 5 women of the group. The figures suggest that it is not sufficient to design a meal for the people with the highest energy requirements and merely give less of it to less active workers.

TABLE 3

Comparison of the Midday Meal Supplied by the Canteen, the Average Meal Eaten in the Canteen, and the Meal Eaten at Home

\begin{tabular}{|c|c|c|c|c|c|c|c|c|c|c|}
\hline Meal & $\begin{array}{c}\text { Calo- } \\
\text { ries }\end{array}$ & $\begin{array}{c}\text { Pro- } \\
\text { tein } \\
\text { g. }\end{array}$ & $\begin{array}{c}\text { Fat } \\
\text { g. }\end{array}$ & $\begin{array}{c}\text { Cal- } \\
\text { cium } \\
\text { mg. }\end{array}$ & $\begin{array}{c}\text { Iron } \\
\text { mg. }\end{array}$ & $\begin{array}{c}\text { Vita- } \\
\text { min } \\
\text { A } \\
\text { I.U. }\end{array}$ & $\begin{array}{c}\text { Vita- } \\
\text { min } \\
\text { B }_{1} \\
\text { mg. }\end{array}$ & $\begin{array}{c}\text { Ribo- } \\
\text { flavin } \\
\text { mg. }\end{array}$ & $\begin{array}{l}\text { Nico- } \\
\text { tinic } \\
\text { acid } \\
\text { mg. }\end{array}$ & $\begin{array}{c}\text { Vita- } \\
\text { min } \\
\mathrm{C} \\
\mathrm{mg} .\end{array}$ \\
\hline $\begin{array}{l}\text { Average meal available } \\
\text { in the canteen } \\
\text { Average meal eaten in } \\
\text { the canteen } \\
\text { Average meal eaten at } \\
\text { home .. }\end{array}$ & $\begin{array}{l}850 \\
630 \\
510\end{array}$ & $\begin{array}{l}21 \\
16 \\
16\end{array}$ & $\begin{array}{l}35 \\
29 \\
17\end{array}$ & $\begin{array}{l}200 \\
140 \\
200\end{array}$ & $\begin{array}{l}5 \\
3 \\
3\end{array}$ & $\begin{array}{c}130 \\
110 \\
1650^{*}\end{array}$ & $\begin{array}{c}0.51 \\
0.27 \\
0.39\end{array}$ & $\begin{array}{l}0.27 \\
0.16 \\
0.40\end{array}$ & $\begin{array}{l}3 \cdot 7 \\
1 \cdot 7 \\
4 \cdot 3\end{array}$ & $\begin{array}{r}18 \\
7 \\
15\end{array}$ \\
\hline
\end{tabular}

* During the days of the survey more carrots were used in the home than in the canteen. 
The difference between the meal available and the meal eaten is, of course, due to the fact that the women, whose total intake was about 2500 Calories, did not buy the whole of the 850 Calorie meal offered to them.

\section{The Effect of Shift Times on Dietary Palterns}

A study of the nutrition of a group of railway workers demonstrates other complications of industrial feeding. These people were men unloading waggons at a London goods depot and their working hours were affected by the times of arrival of the trains. Table 4 shows the average diet of a group working on a shift from $6 \mathrm{a} . \mathrm{m}$. to $3 \mathrm{p} . \mathrm{m}$. These men ate a snack at the canteen at 8 a.m. At 1 p.m. they were intended to eat a complete hot dinner but, owing to the fact that they knew they were leaving work at 3 p.m., they often instead at 1 p.m. ate a meal comprising the pudding from the dinner with a glass of beer, which they called a snack. Their real dinner, with meat and vegetables, became so delayed by this procedure that the meal, tea, customarily eaten at 6 p.m., was squeezed out and the day's diet thereby restricted to 5 meals.

TABLE 4

Calculated Nutritive Value of the Average Meals of Men Working in a RaILWAY GoOdS YaRd ON THE ShIFT From 6 A.M. TO 3 P.M.

\begin{tabular}{|c|c|c|c|c|c|c|c|c|c|c|c|}
\hline Meal & Time & $\begin{array}{l}\text { Calo- } \\
\text { ries }\end{array}$ & $\begin{array}{l}\text { Pro- } \\
\text { teinn } \\
\mathbf{g} .\end{array}$ & $\begin{array}{c}\text { Fat } \\
\mathrm{g} .\end{array}$ & $\begin{array}{c}\text { Cal- } \\
\text { cium } \\
\text { mg. }\end{array}$ & $\begin{array}{l}\text { Iron } \\
\text { mg. }\end{array}$ & $\begin{array}{c}\text { Vita- } \\
\min _{\mathrm{A}} \\
\text { I.U. }\end{array}$ & $\begin{array}{c}\text { Vita- } \\
\min _{\mathbf{B}_{1}} \\
\text { mg. }\end{array}$ & $\begin{array}{l}\text { Ribo- } \\
\text { flavin } \\
\text { mg. }\end{array}$ & $\begin{array}{l}\text { Nico- } \\
\text { tinic } \\
\text { acid } \\
\text { mg. }\end{array}$ & 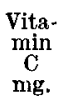 \\
\hline $\begin{array}{l}\text { 1. Breakfast } \\
\text { 2. Snack } \\
\text { 3. Snack } \\
\text { 4. Dinner } \\
\text { 5. Supper }\end{array}$ & $\begin{array}{l}5 \mathrm{a} . \mathrm{m} . \\
8 \mathrm{a.m.} \\
1 \mathrm{p.m} . \\
4 \mathrm{p.m.} \\
9 \mathrm{p.m.} .\end{array}$ & $\begin{array}{l}600 \\
680 \\
580 \\
790 \\
900\end{array}$ & $\begin{array}{l}17 \\
29 \\
11 \\
36 \\
19\end{array}$ & $\begin{array}{l}16 \\
31 \\
23 \\
19 \\
21\end{array}$ & $\begin{array}{l}220 \\
610 \\
210 \\
210 \\
320\end{array}$ & $\begin{array}{l}3 \\
3 \\
2 \\
6 \\
6 \\
3\end{array}$ & $\begin{array}{r}330 \\
1190 \\
120 \\
420 \\
460\end{array}$ & $\begin{array}{l}0.39 \\
0 \cdot 39 \\
0 \cdot 36 \\
0 \cdot 69 \\
0 \cdot 36\end{array}$ & $\begin{array}{l}0-27 \\
0-32 \\
0-28 \\
0-51 \\
0-81\end{array}$ & $\begin{array}{l}0 \cdot 9 \\
1 \cdot 3 \\
2 \cdot 6 \\
7 \cdot 0 \\
1 \cdot 3\end{array}$ & $\begin{array}{r}0 \\
2 \\
6 \\
30 \\
2\end{array}$ \\
\hline \multicolumn{2}{|c|}{ Total daily intake } & 3550 & 112 & 110 & 1570 & 17 & 2520 & $2 \cdot 19$ & $2 \cdot 19$ & $13 \cdot 1$ & 40 \\
\hline
\end{tabular}

The diet can be compared with that of men doing similar work but employed on a shift from 8 a.m. to 5.30 p.m. In this case, a full dinner was eaten at 1 p.m. at the canteen in addition to a snack in the morning at 10 a.m. and another in the afternoon at 4 p.m.

TABLE 5

Calculated Nutritive Value of the Average Meals of Men Workivg in a RAILWAY GOODS YARD ON THE SHIFT FROM 8 A.M. TO 5.30 P.M.

\begin{tabular}{|c|c|c|c|c|c|c|c|c|c|c|c|}
\hline Meal & Time & $\begin{array}{c}\text { Calo- } \\
\text { ries }\end{array}$ & $\begin{array}{c}\text { Pro- } \\
\text { tein } \\
\mathrm{g} .\end{array}$ & $\begin{array}{c}\text { Fat } \\
\text { g. }\end{array}$ & $\begin{array}{c}\text { Cal- } \\
\text { cium } \\
\text { mg. }\end{array}$ & $\begin{array}{l}\text { Iron } \\
\text { mg. }\end{array}$ & $\begin{array}{l}\text { Vita- } \\
\text { min } \\
\text { A } \\
\text { I.U. }\end{array}$ & $\begin{array}{c}\text { Vita- } \\
\text { min } \\
\mathbf{B}_{1} \\
\text { mg. }\end{array}$ & $\begin{array}{c}\text { Ribo- } \\
\text { Havin } \\
\text { mg. }\end{array}$ & $\begin{array}{l}\text { Nico- } \\
\text { timic } \\
\text { acid } \\
\text { mg. }\end{array}$ & $\begin{array}{c}\text { Vita- } \\
\text { min } \\
\mathbf{C} \\
\mathrm{mg} .\end{array}$ \\
\hline $\begin{array}{l}\text { 1. Breakfast } \\
\text { 2. Snack } \\
\text { 3. Dinner } \\
\text { 4. Snack } \\
\text { 5. Tea } \\
\text { 6. Supper } \\
\text {. }\end{array}$ & $\begin{array}{r}6.30 \text { a.m. } \\
10 \text { a.m. } \\
1 \text { p.m. } \\
4 \text { p.m. } \\
6 \text { p.m. } \\
10 \text { p.m. }\end{array}$ & $\begin{array}{l}340 \\
760 \\
710 \\
440 \\
800 \\
430\end{array}$ & $\begin{array}{l}10 \\
29 \\
31 \\
10 \\
24 \\
12 \\
\end{array}$ & $\begin{array}{l}12 \\
31 \\
20 \\
.13 \\
33 \\
10 \\
\end{array}$ & $\begin{array}{l}130 \\
510 \\
340 \\
120 \\
190 \\
250 \\
\end{array}$ & $\begin{array}{l}1 \\
\mathbf{5} \\
6 \\
2 \\
5 \\
\mathbf{2} \\
\end{array}$ & $\begin{array}{l}180 \\
870 \\
320 \\
140 \\
310 \\
320 \\
\end{array}$ & $\begin{array}{l}0 \cdot 27 \\
0 \cdot 45 \\
0 \cdot 54 \\
0 \cdot 21 \\
0 \cdot 69 \\
0 \cdot 18 \\
\end{array}$ & $\begin{array}{l}0 \cdot 19 \\
0 \cdot 33 \\
0 \cdot 52 \\
0 \cdot 14 \\
0 \cdot 25 \\
0 \cdot 41 \\
\end{array}$ & $\begin{array}{l}1 \cdot 4 \\
2 \cdot 1 \\
8 \cdot 4 \\
0 \cdot 5 \\
3 \cdot 4 \\
0 \cdot 6 \\
\end{array}$ & $\begin{array}{r}0 \\
3 \\
13 \\
0 \\
3 \\
1 \\
\end{array}$ \\
\hline \multicolumn{2}{|c|}{ Total daily intake } & 3480 & 116 & 119 & 1540 & 21 & 2140 & $2 \cdot 34$ & $1 \cdot 84$ & $16 \cdot 4$ & 20 \\
\hline
\end{tabular}

Thus it appears that due to a comparatively minor alteration in shift times the proportion of the day's diet provided by the canteen was increased from 35 to 55 per cent, and the number of daily meals from 5 to 6 . voL. 3,1945 ] 


\section{One Big Meal or Two Smaller Ones}

Let us turn now to a comparison between two groups of different types of workers. The first were shipbuilders on the Clyde. These men worked from 7.45 a.m. until 5.15 p.m. During this time they ate a hot canteen meal supported by 2 small snacks which were officially discouraged by the management of the shipyard by means of halfcrown fines imposed on those found eating them. The canteen meal was a substantial one as can be seen from Table 6 .

TABLE 6

Calculated Nutritive Value of the Average Meals Eaten by Shipyard WORKERS

\begin{tabular}{|c|c|c|c|c|c|c|c|c|c|c|c|}
\hline Meal & Time & $\begin{array}{l}\text { Calo- } \\
\text { ries }\end{array}$ & $\begin{array}{c}\text { Pro- } \\
\text { tein } \\
\text { g. }\end{array}$ & $\begin{array}{c}\text { Fat } \\
\text { g. }\end{array}$ & $\begin{array}{l}\text { Cal- } \\
\text { cium } \\
\text { mg. }\end{array}$ & $\begin{array}{l}\text { Iron } \\
\text { mg. }\end{array}$ & $\begin{array}{c}\text { Vita- } \\
\text { min } \\
\text { A. } \\
\text { I.U. }\end{array}$ & $\begin{array}{c}\text { Vita- } \\
\text { min } \\
\mathbf{B}_{1} \\
\text { mg. }\end{array}$ & $\begin{array}{l}\text { Ribo- } \\
\text { flavin } \\
\text { mg. }\end{array}$ & $\begin{array}{l}\text { Nico- } \\
\text { tinic } \\
\text { acid } \\
\text { mg. }\end{array}$ & $\begin{array}{c}\text { Vita- } \\
\text { min } \\
\text { mg. } \\
\text { mig. }\end{array}$ \\
\hline $\begin{array}{l}\text { 1. Breakfast } \\
\text { 2. "Piece"" } \\
\text { 3. Canteen }\end{array}$ & $\begin{array}{r}7 \text { a.m. } \\
9.30 \text { a.m. }\end{array}$ & $\begin{array}{l}440 \\
270\end{array}$ & $\begin{array}{l}15 \\
10\end{array}$ & $\begin{array}{r}16 \\
9\end{array}$ & $\begin{array}{l}280 \\
170\end{array}$ & $\begin{array}{l}2 \\
2\end{array}$ & $\begin{array}{l}510 \\
230\end{array}$ & $\begin{array}{l}0.24 \\
0.18\end{array}$ & $\begin{array}{l}0 \cdot 23 \\
0 \cdot 11\end{array}$ & $\begin{array}{l}0.7 \\
0 \cdot 6\end{array}$ & $\begin{array}{l}0 \\
0\end{array}$ \\
\hline $\begin{array}{l}\text { dinner. } \\
\text { 4. "Plece" } \\
\text { 5. Tea } \\
\text { 6. Supper . }\end{array}$ & $\begin{array}{r}12 \text { noon } \\
3 \text { p.m. } \\
6 \text { p.m. } \\
10 \text { p.m. }\end{array}$ & $\begin{array}{l}950 \\
160 \\
790 \\
730\end{array}$ & $\begin{array}{r}43 \\
6 \\
42 \\
8\end{array}$ & $\begin{array}{r}43 \\
3 \\
30 \\
6\end{array}$ & $\begin{array}{l}380 \\
100 \\
250 \\
190\end{array}$ & $\begin{array}{l}8 \\
1 \\
5 \\
1\end{array}$ & $\begin{array}{r}780 \\
120 \\
810 \\
90\end{array}$ & $\begin{array}{l}0.72 \\
0.12 \\
0.63 \\
0.45\end{array}$ & $\begin{array}{l}0.72 \\
0.08 \\
0.52 \\
0.16\end{array}$ & $\begin{array}{r}10 \cdot 9 \\
0.3 \\
5.8 \\
0.7\end{array}$ & $\begin{array}{r}34 \\
0 \\
11 \\
0\end{array}$ \\
\hline \multicolumn{2}{|c|}{ Total daily intake } & 3340 & 124 & 107 & 1370 & 19 & 2540 & $2 \cdot 34$ & $1 \cdot 82$ & $19 \cdot 0$ & 45 \\
\hline
\end{tabular}

For comparison with these men, we can take in a neighbouring mill a group of steel roller men engaged on the arduous job of rolling red hot steel sheets (Table 7). These men, when they were on the morning shift, worked from 6 a.m. to 2 p.m. Their canteen did not attcmpt to serve a conventional hot meal but, at 8 a.m., ham sandwiches, egg sandwiches, milk and porridge were provided and again at 11 a.m. substantial amounts of bread and jam and tea were made available. With the exception of nicotinic acid and vitamin C, these 2 meals together provided, in proportion to the total day's diet, as much as, or more than, the single cooked meal of the shipyard workers.

TABLE 7

Calculated Nutritive Value of the Average Meals Eaten by Men Working in a Steel Rolling Mill during the 6 a.m. to 2 p.M. Shift

\begin{tabular}{|c|c|c|c|c|c|c|c|c|c|c|c|}
\hline Meal & Time & $\begin{array}{c}\text { Calo- } \\
\text { ries }\end{array}$ & $\begin{array}{l}\text { Pro- } \\
\text { tein } \\
\mathrm{g} .\end{array}$ & $\begin{array}{c}\text { Fat } \\
g .\end{array}$ & $\begin{array}{c}\text { Cal- } \\
\text { cium } \\
\text { mg. }\end{array}$ & $\begin{array}{l}\text { Iron } \\
\text { mg. }\end{array}$ & $\begin{array}{l}\text { Vita- } \\
\text { min } \\
\text { I.U. }\end{array}$ & $\begin{array}{c}\text { Vita- } \\
\text { min } \\
\mathbf{B}_{1} \\
\text { mg. }\end{array}$ & $\begin{array}{c}\text { Ribo- } \\
\text { flavin } \\
\text { nng. }\end{array}$ & $\begin{array}{l}\text { Nico- } \\
\text { tinic } \\
\text { acid } \\
\text { nig. }\end{array}$ & $\begin{array}{l}\text { Vita- } \\
\text { nin } \\
\mathrm{C} \\
\text { mig. }\end{array}$ \\
\hline 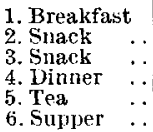 & $\begin{array}{r}5.30 \mathrm{a} . \mathrm{m} . \\
8 \mathrm{a} . \mathrm{m} . \\
11 \mathrm{a.m} . \\
3 \mathrm{p.m} . \\
6 \mathrm{p.m} . \\
10 \text { p.m. }\end{array}$ & $\begin{array}{r}410 \\
880 \\
410 \\
840 \\
610 \\
1000\end{array}$ & $\begin{array}{l}11 \\
31 \\
13 \\
31 \\
23 \\
22\end{array}$ & $\begin{array}{r}18 \\
35 \\
4 \\
25 \\
21 \\
27\end{array}$ & $\begin{array}{l}160 \\
410 \\
170 \\
250 \\
340 \\
390\end{array}$ & $\begin{array}{l}2 \\
6 \\
3 \\
6 \\
4 \\
2\end{array}$ & $\begin{array}{r}270 \\
600 \\
130 \\
350 \\
1120 \\
510\end{array}$ & $\begin{array}{l}0 \cdot 21 \\
0.69 \\
0.30 \\
0.78 \\
0.42 \\
0.12\end{array}$ & $\begin{array}{l}0.17 \\
0.59 \\
0.20 \\
0.51 \\
0.30 \\
0.23\end{array}$ & $\begin{array}{l}1 \cdot 1 \\
3 \cdot 9 \\
0 \cdot 7 \\
7 \cdot 5 \\
2 \cdot 0 \\
1 \cdot 8\end{array}$ & $\begin{array}{r}0 \\
0 \\
0 \\
35 \\
10 \\
2\end{array}$ \\
\hline \multicolumn{2}{|c|}{ Total daily intake } & 4150 & 131 & 130 & 1720 & 23 & 2980 & $2 \cdot 52$ & $2 \cdot 00$ & $17 \cdot 0$ & 17 \\
\hline
\end{tabular}

\section{Conclusion}

In this brief paper there has been no time to discuss the details of the nutritive composition of meals which might ideally be served in the canteens of different industries. An attempt has, however, been made to demonstrate at least 3 of the ways in which industrial work may affect 
nutrition. Firstly, observation of the cotton spinners showed that widely differing calorific needs may exist in a single superficially homogeneous industry. Secondly, the behaviour of the railwaymen exemplified the way in which even a slight modification in working times may affect the whole dietary pattern. Thirdly, the contrast between the habits of shipbuilders and steel workers posed the question as to whether a hot meal, or a so called snack, or a combination of both, could best satisfy the nutritional needs of workpeople in given circumstances.

A final point of considerable interest arises from the study of the nutrition of coalminers. These people eat a "snap" underground halfway through their working shift. There is no obvious physiological reason why the amount of nutrients provided by the sandwiches which make up this meal should voluntarily be varied between one district and another. Yet this is the case, and the variation in nutritional value is related to the distribution of a strong and equally mysterious prejudice against cheese! The figures are shown in Table 8.

TABLE 8

A Comparison of the Food Eaten Underground by Coalminers in DIFFERENT DISTRICTS

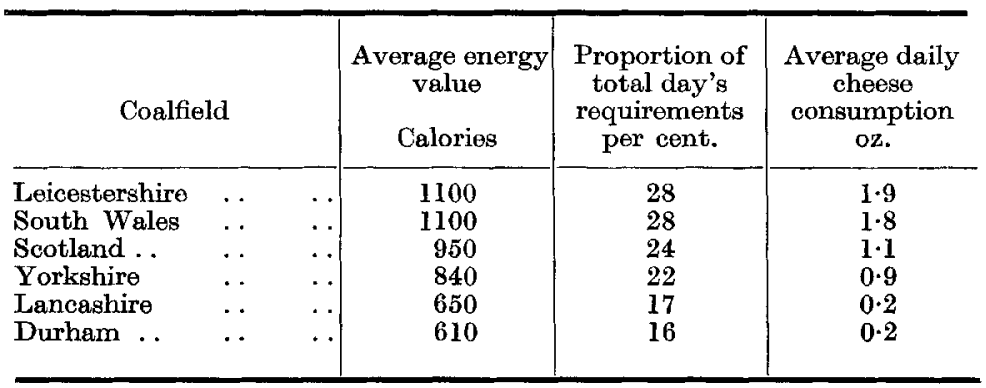

Are such traditional variations in the habits of men doing similar work important or not? Here is one more problem awaiting solution by the application of scientifie study to industrial nutrition.

\section{Reference}

Wiehl, D. G. (1942). Milbank Mem. Fd Quart. 20, 329.

\section{Hospital Diets}

\section{Dr. A. Lyall (Department of Clinical Chemistry, Royal Infirmary, Aberdeen)}

In assessing the adequacy of hospital diets certain factors have to be considered which do not apply with the same force to surveys of the diet of the general population. Food supply in large institutions is, in general, more standardized than for smaller family groups and, while food consumption by healthy members of the nursing staff approximates to that of the healthy general population, food consumption by patients is complicated by issues which may not appear at first sight.

vor. 3,1945$]$ 
Food supply to a large institution is arranged by contract in advance. Preparation and cooking are more or less uniform in each institution.

Distribution to wards and service to patients is worked out in detail in the well run hospital so that proper regard is had for foods which are in season. I do not mean to infer that these essential proceedings are always conducted to the greatest advantage but it should be possible to arrange commissariat, cooking, distribution and serving so as to utilize available foods satisfactorily.

Marketing and contracts should be in the control of persons well acquainted with the conditions of basic food supply in their area and able to take advantage of seasonal supplies to provide variety. Kitchen staffs and cooks should have adequate training and possess sufficient enthusiasm and interest to avoid institutional monotony. Cooking apparatus and distribution trolleys of the best types are essential.

The special questions applicable to the diet of hospital patients include: (1) The optimum basic calorie value of the diet; (2) the allowance to be made for extra foods carried into hospital by friends; (3) the adjustments necessary in making calculations for $(a)$ patients on special diets, (b) patients temporarily unable to share in general food distribution; (4) the different types of diet desirable for general hospitals, maternity hospitals, sanatoria, convalescent homes and so forth.

Certain of the questions can be answered only on the basis of collected data; others must be considered as matters of general principle.

\section{Actual Calorie Values of Diets}

A number of observations has been made on diets in a general hospital of 500 beds, in an associated maternity hospital of 70 beds, and in a hospital for chronic diseases of 105 beds. Data are available for the diets of the patients and of the nursing staff. We should keep in mind in considering these figures that comparison must be made with the war time diet available to the general population as standard, since rationed foods with the exception of milk and eggs are distributed nearly equally to the healthy and the sick. The rationed foods available to all with average additions of non-rationed foods such as bread, potatoes and vegetables give a Calorie value of 2100 derived from $250 \mathrm{~g}$. carbohydrate, $80 \mathrm{~g}$. protein and $87 \mathrm{~g}$. fat. This may be increased by the individual by greater intake of cheap unrationed foods like bread and vegetables or of more expensive ones like fish, game, salmon and so forth.

\section{Diets in a General Hospital}

The hospital studied was one of 500 beds which supplied cooked meals also for the smaller maternity hospital on the same site. For one month the daily diets of 434 members of staff and 550 patients were studied. Records were kept of the cooked foods delivered to a single ward for 8 consecutive days. The food values are set out in Table 1, and, in round figures, were daily $190 \mathrm{~g}$. carbohydrate, $70 \mathrm{~g}$. protein and $70 \mathrm{~g}$. fat, giving a Calorie value of 1700 with, for any one day, a maximum of 1940 and a minimum of 1540. Actual waste in serving and food returned uneaten was small, amounting to 4 per cent., a quantity equivalent to the food for 20 patients daily over the total of 500 occupied beds. In the particular 


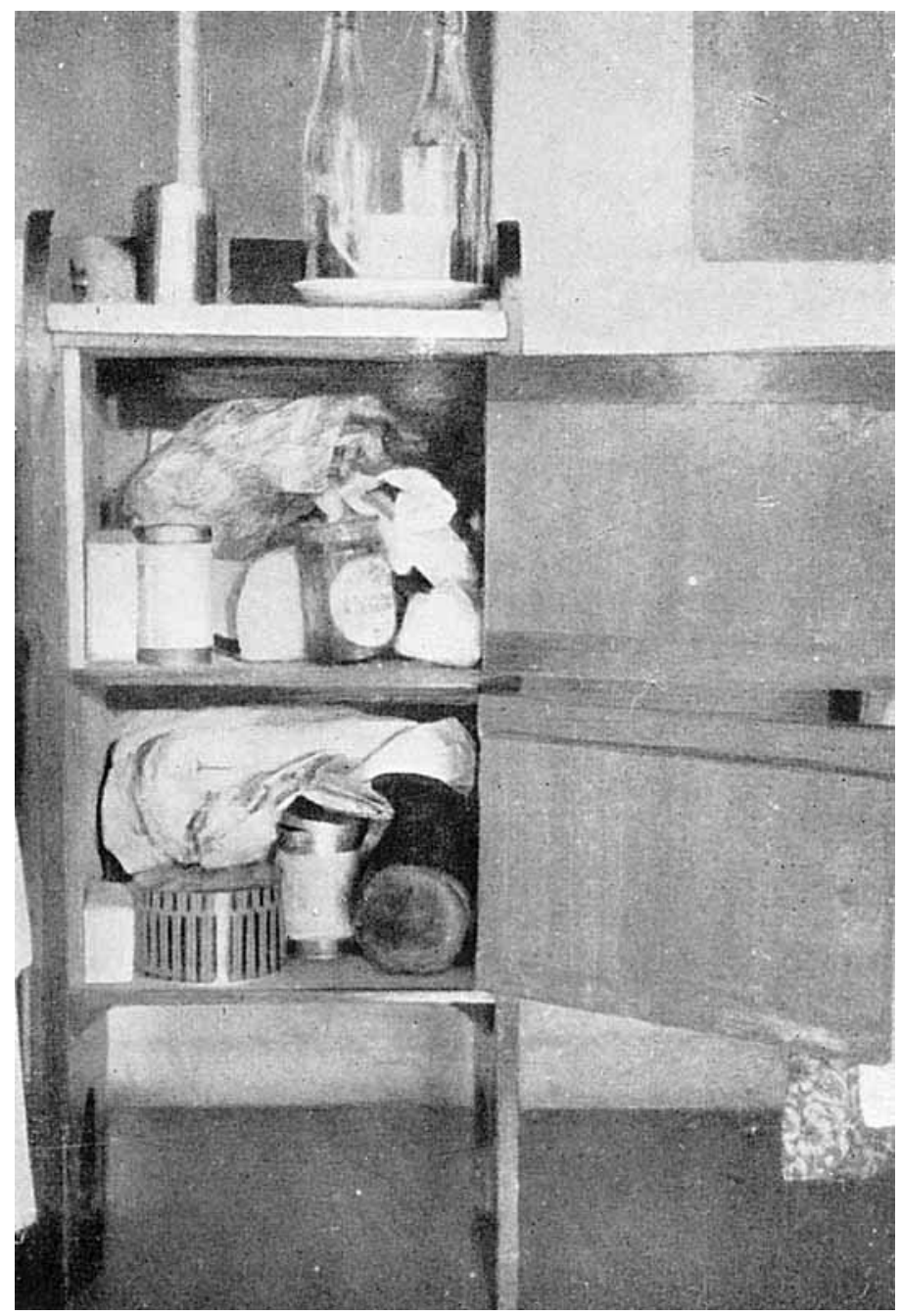

Figure 1. Contents of a Patient's Bedside Locker in the Ward of a General Hospital. 
TABLE 1

Nutritive Value of Ward Diets in a General Hospital

\begin{tabular}{|c|c|c|c|c|c|c|}
\hline Day & $\begin{array}{l}\text { No. of } \\
\text { patients }\end{array}$ & & $\begin{array}{c}\text { Carbohydrate } \\
\text { g. }\end{array}$ & $\begin{array}{l}\text { Protein } \\
\text { g. }\end{array}$ & $\begin{array}{c}\text { Fat } \\
\text { g. }\end{array}$ & Calories \\
\hline I & 24 & (a) & 198 & 61 & 64 & 1650 \\
\hline \multirow[t]{2}{*}{2} & 22 & (a) & 205 & 62 & 93 & 1950 \\
\hline & & (b) & 204 & 61 & 91 & 1900 \\
\hline \multirow[t]{2}{*}{3} & 24 & (a) & 188 & 76 & 80 & 1830 \\
\hline & & (b) & 186 & 74 & 76 & 1780 \\
\hline \multirow[t]{2}{*}{4} & 23 & (a) & 184 & 71 & 73 & 1730 \\
\hline & & (b) & 177 & 68 & 72 & 1680 \\
\hline \multirow[t]{2}{*}{5} & 24 & (a) & 181 & 68 & 64 & 1620 \\
\hline & & (b) & 170 & 66 & 60 & 1560 \\
\hline \multirow[t]{2}{*}{6} & 24 & (a) & 203 & 77 & 84 & 1940 \\
\hline & & (b) & 181 & 64 & 78 & 1760 \\
\hline \multirow[t]{2}{*}{7} & 25 & $(a)$ & 162 & 67 & 64 & 1540 \\
\hline & & $(b)$ & 162 & 65 & 64 & 1530 \\
\hline \multirow[t]{2}{*}{8} & 25 & $(a)$ & 221 & 76 & 66 & 1730 \\
\hline & & (b) & 198 & 66 & 63 & 1670 \\
\hline \multicolumn{2}{|r|}{ Average } & $\begin{array}{l}(a) \\
(b)\end{array}$ & $\begin{array}{l}193 \\
183\end{array}$ & $\begin{array}{l}70 \\
65\end{array}$ & $\begin{array}{l}73 \\
70\end{array}$ & $\begin{array}{l}1760 \\
1680\end{array}$ \\
\hline
\end{tabular}

(a) Total food value of meal. (b) Net food value of meal after waste has been allowed for.

ward sampled, food returned was mostly accounted for by unconsumed soups and broths of which 1 pint per person was provided and less than half a pint consumed.

In addition, careful records were kept for 2 periods of a week in 4 wards in the hospital of the extra food, including sweets and sweet drinks, brought in by patients' friends.

For 136 patients for 14 days, the average daily additions from this source were $65 \mathrm{~g}$. carbohydrate, $11 \mathrm{~g}$. protein and $22 \mathrm{~g}$. fat, giving 500 Calories (Table 2). These additions raised the average daily food intake per patient to $255 \mathrm{~g}$. carbohydrate, $80 \mathrm{~g}$. protein, and $90 \mathrm{~g}$. fat, with a Calorie value of 2220. The number of eggs in these additions was largely due to the fact that a large proportion of the patients belonged to country districts.

In taking the average value per patient, however, no cognizance was taken of the facts that some patients are too ill to eat and that some get far more extras than others. In any general hospital more than half the patients are on light diets and a few are on special diets or milk only, as shown in Table 3 for the institution under consideration.

This probably means that certain patients receive more than the average of 2200 Calories, and a number receive less. There is also a margin of waste in the utilization of extras, since these foods are kept by the patients in their individual lockers and may deteriorate before they can be used. Extra foods brought in by friends should be stored in a larder for the purpose under the care of the ward sister who would use them to the best advantage. This would limit waste, and avoid unhygienic collections of food in lockers at the bedside (Figure 1).

จoL. 3, 1945] 
TABLE 2

Extra Food Brought to Patients durina a Forthight in a General Hospital

\begin{tabular}{|c|c|c|c|c|c|}
\hline \multirow[b]{2}{*}{ Ward } & \multirow{2}{*}{$\begin{array}{l}\text { No. of } \\
\text { patients }\end{array}$} & \multicolumn{4}{|c|}{ Extra food per patient } \\
\hline & & $\begin{array}{c}\text { Carbohydrate } \\
\text { g. }\end{array}$ & $\begin{array}{c}\text { Protein } \\
\text { g. }\end{array}$ & $\begin{array}{c}\text { Fat } \\
\mathrm{g} .\end{array}$ & Calories \\
\hline \multirow[t]{2}{*}{$\begin{array}{l}3 \mathrm{~F}^{2} \\
3 \mathrm{M} \\
8 \\
\text { Matern } \\
4 \mathrm{M} \\
4 \mathrm{~F}\end{array}$} & $\begin{array}{l}14 \\
34 \\
48 \\
18 \\
10 \\
12\end{array}$ & $\begin{array}{r}114 \\
66 \\
62 \\
54 \\
12 \\
83\end{array}$ & $\begin{array}{r}16 \\
16 \\
10 \\
5 \\
6 \\
14\end{array}$ & $\begin{array}{l}33 \\
24 \\
18 \\
12 \\
15 \\
29\end{array}$ & $\begin{array}{l}825 \\
544 \\
450 \\
338 \\
207 \\
649\end{array}$ \\
\hline & Total 136 & Average 65 & 11 & 22 & 502 \\
\hline \multirow{2}{*}{ Range } & Maximum & 114 & 20 & 42 & 866 \\
\hline & Minimum & 12 & 0 & 0 & 60 \\
\hline
\end{tabular}

TABLE 3

Number of Patients Receiving Lighty and Special Diets in a General Hospital AVERAGE FOR 1 MONTH

\begin{tabular}{|c|c|c|c|c|c|c|c|c|}
\hline & \multirow[b]{2}{*}{ Total } & \multirow{2}{*}{$\begin{array}{l}\text { Full } \\
\text { diet }\end{array}$} & \multicolumn{4}{|c|}{ Light diet } & \multirow{2}{*}{$\begin{array}{c}\text { Special } \\
\text { diet }\end{array}$} & \multirow{2}{*}{$\begin{array}{l}\text { Milk } \\
\text { only }\end{array}$} \\
\hline & & & Chicken & Fish & Mince & Rabbit & & \\
\hline No. of patients. & 476 & 226 & 32 & 55 & 75 & 30 & 32 & 26 \\
\hline Per cent. & 100 & $47 \cdot 5$ & \multicolumn{4}{|c|}{$40 \cdot 3$} & $6 \cdot 7$ & $5 \cdot 5$ \\
\hline
\end{tabular}

\section{Diets in a Maternity Hospital}

The diet was studied by weighing all foods cooked as sent from the central kitchen daily for a period of 7 days. This eliminated the factor of cooking waste and provided a broad basis for the calculation of the individual daily diet. In a first survey in 1943 , the diet provided $230 \mathrm{~g}$. carbohydrate, $66 \mathrm{~g}$. protein of which $40 \mathrm{~g}$. were of animal origin, and $67 \mathrm{~g}$. fat, with a Calorie value of 1840 . The milk supply was the maximum for expectant and nursing mothers, 1.07 pints daily. There was some retrospective discussion as to whether the milk and milk powder used for making milk puddings was additional to this milk supply. The milk powder and rice were certainly additional and are included in the estimate. The content in the diet of calcium was $1.08 \mathrm{~g}$., of iron $13 \mathrm{mg}$., of vitamin $\mathrm{B}_{1} 430 \mathrm{I}$.U., of vitamin C $33 \mathrm{mg}$. and of vitamin D $28 \mathrm{I} . \mathrm{U}$. It was considered that the diet was deficient in total calories, and in some vitamins, low in animal protein, and lacking in vegetables. From the point of view of the patient the diet was lacking in any substantial meal after the midday dinner. It was suggested that carrots, turnips, kale, cabbage, and lettuce should be added, that the carbohydrate should be increased by an addition such as oatcake, that extra cheese and dripping should be given and that cod liver oil should be added. 
The diet was reviewed some months later after improvements had been made. The principal alteration was a meal of the nature of a high tea consisting of ham, bacon, skirley or pie. The ration of meat was increased and fruit added. Salads were tried but it was found that they were not eaten. Two pints of porridge and 1 egg were deducted weekly. The improved diet provided $260 \mathrm{~g}$. carbohydrate, $80 \mathrm{~g}$. protein, $85 \mathrm{~g}$. fat and 2200 Calories, and showed an increase in the amounts of protein and fat. The calorie value was probably not sufficient for a lactating mother even at rest, unless she had stored 8 to 10 pounds of adipose tissue during pregnancy and could mobilize this reserve.

A record was made at the same time of additional foods brought into the hospital by patients' friends for 2 weeks. This addition increased the nutritive value of the diet by an average daily amount of $54 \mathrm{~g}$. carbohydrate, $5 \mathrm{~g}$. protein, $12 \mathrm{~g}$. fat and 338 Calories, giving a total Calorie value of 2540. The eggs brought were only a few since most of the patients belonged to city homes.

The feeding of patients in a maternity hospital differs markedly from that of patients in a general hospital. The mothers, unless some severe complication occurs, are soon able to consume a full diet. These patients on leaving hospital will have to attend to the wants of their families, and should have the opportunity while in the maternity ward of seeing the correct foods properly prepared and served. The diet in maternity hospitals should, therefore, be the best possible in both quantity and quality, and the opportunity should be taken to make the period spent in hospital of educative value in this respect. Even a small hospital could thus influence up to 1000 mothers within a year.

The optimum calorie value depends to some extent on the individual. In underweight mothers, the Calorie value of the diet should approach 3000 ; in mothers of nearly ideal weight 2800 should suffice; in overweight mothers a diet in excess of 2500 Calories is not desirable on account of the frequency with which obesity supervenes in pregnancy, particularly in multiparae.

\section{Diets in a Hospital for Chronic Diseases}

I am indebted to Prof. E. W. H. Cruickshank of the Department of Physiology, Aberdeen University, for permission to quote the following figures collected in a hospital with a staff of 43 , and 105 beds for chronically sick patients liable to stay for months or years or permanently in hospital. For 73 female patients the average daily diet gave 1940 Calories with $243 \mathrm{~g}$. carbohydrate, $62 \mathrm{~g}$. protein and $77 \mathrm{~g}$. fat and, for 32 male patients, 2150 Calories with $300 \mathrm{~g}$. carbohydrate, $60 \mathrm{~g}$. protein and $70 \mathrm{~g}$. fat. No account was taken of any extras brought by patients' friends. The content of calcium was $0.8 \mathrm{~g}$., of iron $12 \mathrm{mg}$., and of vitamin C $50 \mathrm{mg}$. The general state of nutrition of patients kept for long periods on diets of this nature should be a good test of the adequacy of the diet.

The dicts in these 3 hospitals as summarized in Table 4 compare favourably in their values for proximate principles and calories with those of the Memorandum of King Edward's Hospital Fund for London (1943). In that work the estimates were made by actual analysis of single meals daily for 1 patient over a week. No account was taken of any extras in the way of sweets, lemonade or foods brought by patients' friends. For vos, 3, 1945] 
male and female patients in the 3 London hospitals investigated, the average Calorie value was 1300 with $49 \mathrm{~g}$. protein and $4 \mathrm{l} \mathrm{g}$. fat daily.

TABLE 4

Summary of Nutritive Value of Diets of Patients in Different Hospitals

\begin{tabular}{|c|c|c|c|c|c|}
\hline Hospital & No. of beds & $\begin{array}{c}\text { Carbohydrate } \\
\text { g. }\end{array}$ & $\begin{array}{l}\text { Protein } \\
\text { g. }\end{array}$ & $\begin{array}{c}\text { Fat } \\
\text { g. }\end{array}$ & Calories \\
\hline General $\quad .$. & 500 & $\begin{array}{l}183 \\
255^{*}\end{array}$ & $\begin{array}{l}65 \\
80^{*}\end{array}$ & $\begin{array}{l}70 \\
90^{*}\end{array}$ & $\begin{array}{l}1680 \\
2220^{*}\end{array}$ \\
\hline Maternity $\quad . \quad$. & 70 & $\begin{array}{l}260 \\
314^{*}\end{array}$ & 80 & $\begin{array}{l}85 \\
97^{*}\end{array}$ & $\begin{array}{l}2200 \\
2540^{*}\end{array}$ \\
\hline For chronic diseases & 105 & 286 & 63 & 74 & 2130 \\
\hline
\end{tabular}

* Including extras brought by friends.

From the data in the hospitals reviewed here the following conclusions can be drawn. The total food value of the diets is nearly adequate provided the quality and serving is maintained at the optimum, and additions from friends are included. If these should cease, the hospital must raise its basic diet by 500 Calories at least, as is indeed the accepted policy in this eventuality. In maternity and convalescent hospitals, the diet should reach optimum standards.

For co-operation in this investigation I am indebted to the superintendent and steward of the hospitals concerned and to the sister of the dietetic department.

\section{RefERENCE}

King Edward's Hospital Fund for London (1943). Memorandum on Hospital Diet. London: Geo. Barber and Son, Ltd.

\section{Discussion}

Miss M. C. Broatch (King Edward's Hospital Fund, 10 Old Jewry, London, E.C.2), opener: In opening the discussion on the 3 papers which you have just heard, I am confining my remarks chiefly to 2 papers only, firstly because I am more familiar with work in connexion with school meals and hospitals, and secondly because Dr. Pyke has given so much information that I cannot deal with all of the points. I would like to say how impressed I am with the nutritional value obtained from the 6 meals a day. We ought to consider our whole system of feeding and divide out our calories into 4 , rather than 3 , main meals a day.

There are 2 points raised by Miss Langley's paper especially calling for comment. She mentioned that the Oslo breakfast had the administrative disadvantage that it took longer to eat than a 2 course hot dinner, the children having to stay in for at least half an hour in order to masticate it properly. In this way, however, the advantage is secured that the children obtain a proper rest; it is the common practice in London to have too short a time for meals because the children want to get out to play, and the people who supervise the meal are anxious to have their own dinner. I do think the advantage of the extra time taken to eat the Oslo breakfast is a factor which is contributory to its success. 
The second point in Miss Langley's paper was that of the 1000 Calorie meal. When she spoke of a meal of 1000 Calories, did she mean one which would provide 1000 Calories? We ought not to "kid" ourselves that the children are eating that amount. If we give them raw fruit or stewed fruit and custard, we have to leave out the suet pudding, and it is only by including that that we can keep the calories up. I do not think, therefore, that a meal will average out at 1000 Calories.

In the paper that Dr. Lyall has just read he mentioned that food in large institutions is more standardized than in family groups. I would like to think that Dr. Lyall was referring to the past. We should like to get away from the standardized meal, and the old way of having a certain meal on Mondays and a certain meal on Tuesdays. Rationing has stopped this to a certain extent and I hope it will not come back. Food in institutions is arranged by contracts, but the best meals are supplied in hospitals, for instance, where a buyer is employed, who goes into the markets and buys the best food he can at the best prices. When there is a contract the institution is tied to accept what the supplier sends and all the good foods in the markets are missed. We want, too, to see tremendous changes with staffs who are put in charge of catering. The standard of hospital canteen staffs is not good and, generally speaking, they are not trained people; the man doing the ordering, for instance, is often a person with no experience except that he started in the steward's office and has worked his way up to the office of steward, having received only training that is passed on. The recognized course for sister housekeepers is only a short one and does not include cooking. I do not feel that any woman in charge of the catering can be properly in control of it unless she herself has had training and experience. The result is that at present there is somebody doing the ordering having had no experience, somebody in charge of catering and drawing up of menus and a couple of cooks with no proper training struggling to do the cooking for 500 people, never having been outside the hospital to get a wider experience of cooking.

I think it very wrong for hospitals to depend on the food brought in by relatives. I think the practice has grown because, without help from outside, patients did not get enough to eat. Surely today we have realized that the proper feeding of patients in hospital is an important factor in their recovery. In some hospitals, high tea may pass for a meal. There again, I think hospitals must face the fact that 3 meals should be provided daily by the hospital kitchen. At present, hospitals provide only one main meal. The 3 reasons for these conditions are lack of interest on the part of the staff, lack of staff and lack of equipment.

Hospital kitchens are equipped to prepare one main meal each day and cannot cope with more. Dr. Lyall mentioned also the result of the surveys; the survey figure which was published in the Memorandum of the King Edward's Hospital Fund for London, and which he quoted, was very low and I think it is a pity to take it as a standard for comparison. It is not one of which we are at all proud. Another question raised was the mode of serving the meal. It is amazing to me how often good food can leave the kitchen and yet, before it reaches the patient, it has become a poor meal. The method of conveying food from the kitchen to the ward and from the ward to the patient, and to the staff vox. 3, 1945] 
dining room, is one which should be given a great deal of consideration. If proper equipment is provided, it should be possible to reach the standard of food required. This is one of the weak spots in hospital feeding.

Dr. L. M. Kerly (University College, Gower Street, London, W.C.1): We have heard from Miss Langley of the standard set by the Board of Education. It may be of interest to quote values actually found in a survey of meals served in Surrey schools. Values for calories, protein and fat calculated from the costing sheets of these meals were well up to the Board's standards but the analyses of portions served gave lower figures, probably because the standard portion was smaller than the average allowed by the caterers, the difference being used for second and even third helpings for children with larger appetites. Miss Langley suggested that the meal should supply $50 \mathrm{mg}$. of vitamin $\mathrm{C}$. The highest average for 3 days in any canteen I visited was $35 \mathrm{mg}$. The average over more than 12 canteens was about $25 \mathrm{mg}$., and it is my impression that 25 to $30 \mathrm{mg}$. is a reasonable amount to ask the canteen to supply; with the present equipment it is not possible to aim at anything higher.

The question of cost must be considered in connexion with the supply of vitamin C. A reasonable amount of cabbage as a second helping for older children is $3 \mathrm{oz}$. This works out at $\frac{3}{4} \mathrm{~d}$. per meal, so that to increase its vitamin $\mathrm{C}$ content it is necessary to increase the cost of the meal. We do not find that salad provides much vitamin C. Lettuce is not a suitable source of it. Raw cabbage is good and occasionally children will eat enough to give them a reasonable amount of the vitamin. If watercress is served, children must eat an oz. to get the required amount.

Have the medical people here any evidence that there is a widespread vitamin $\mathrm{C}$ deficiency? I not only suspect that children are getting less than the above amount at school, but I also think they are getting very little extra at home. We tried to make a survey of home meals and, during school term, about one-third of the children never had anything at home that might possibly contain vitamin $\mathrm{C}$; another third ate something that might contain vitamin $\mathrm{C}$, and the remaining third did get quite a bit. We ought to set down what is a reasonable amount of vitamin $\mathrm{C}$ and not aim too high.

Dr. H. E. Magee (Ministry of Health, Whitehall, London, S.W.1): I think there is a good deal of misunderstanding or lack of knowledge as to the first time the Oslo breakfast was tried in this country. The principle was in operation in this country before the Oslo breakfast itself was ever heard of. Dr. Milligan of Glossop worked out a meal on the basis that one should give those nutrients which are calculated to be defieient in the home diet of the children. He incorporated them in a sandwich. That ought to be known because the plan has been in operation from about 1934 onwards.

As regards the evidence for deficiency of vitamin $\mathrm{C}$ in this country, we have 2 clinicians who have taken a clinical training, particularly from the nutritional point of view, from Professor Sydenstricker. In 1942, with his methods and with the help of expcrience of deficiency diseases gained in West Africa, they examined 1500 people, and I do not think a single case of scurvy was seen. Five thousand schoolchildren have 
been examined and $I$ have not come across cases of clear cut deficiency of vitamin $\mathrm{C}$ at all.

I would like to try to enlighten the minds of people who may be under a misapprehension about hospital diets. It is most important that every hospital official should know what food can be obtained as special allowances to hospital patients. Calculations made recently showed that a patient receiving 3000 Calories would, through his priorities, rations, points and sweet coupons, obtain $131 \mathrm{~g}$. of protein of which $78 \mathrm{~g}$. would be of animal origin.

If the hospitals gave their patients all the rations due to them and spent all the available points, there should be no question whatever of any deficiency in any hospital, but, as Miss Broatch pointed out, that is not the case. Many hospitals are not drawing the rations to which they are entitled. Some do not draw all their meat or fats and complain of shortage of fats for cooking. Others do not draw their dried milk or dried eggs.

Miss Broatch referred also to hospitals, both voluntary hospitals and those belonging to the Council, saying that it had been the custom for only one meal a day to be given. This is perfectly true for I have come across such hospitals. The patients have only one square meal; the other meals are bread and margarine. A patient should get a full, complete diet in hospital, and there should be more rigid control over the food brought in by friends, because some of it may be bad for the patients. Rations are the same for everybody in the country and the hospital patient is entitled to his rations. These needs are beginning to dawn on people. The bringing in of food is an old custom which dies hard. The sooner it does so the better.

Dr. J. C. Thompson (Food Research Laboratory, Barkers (Contractors), Ltd., c/o Morris Motors, Ltd., Cowley, Oxford): Through the past 12 months I have been engaged in examining midday meals in canteens run by our firm. The results classified into the 3 groups corresponding with canteen allowances of rationed foods are shown in Table 1 .

TABLE 1

Composition of a Midday Meal Served in Industrial Canteens

\begin{tabular}{|c|c|c|c|c|c|c|c|}
\hline \multicolumn{2}{|c|}{ Canteen } & \multirow[b]{2}{*}{$\begin{array}{l}\text { Nature of } \\
\text { meal }\end{array}$} & \multirow[b]{2}{*}{$\begin{array}{c}\text { Protein } \\
\text { g. }\end{array}$} & \multirow[b]{2}{*}{$\begin{array}{c}\text { Fat } \\
\text { g. }\end{array}$} & \multirow[b]{2}{*}{ Calories } & \multirow[b]{2}{*}{$\begin{array}{c}\text { Calcium } \\
\text { mg. }\end{array}$} & \multirow[b]{2}{*}{$\begin{array}{c}\text { Vitamin } \mathrm{C} \\
\mathrm{mg} .\end{array}$} \\
\hline Category & $\begin{array}{c}\text { No. } \\
\text { examined }\end{array}$ & & & & & & \\
\hline \multirow[t]{3}{*}{ A } & 18 & Average & $24 \cdot 5$ & $26 \cdot 5$ & 760 & 266 & 27 \\
\hline & & Minimum & $16 \cdot 7$ & $6 \cdot 1$ & 389 & 103 & 5 \\
\hline & & Maximum & $40 \cdot 2$ & $71 \cdot 0$ & 1523 & 732 & 83 \\
\hline \multirow[t]{3}{*}{ B } & 49 & Average & $23 \cdot 0$ & $25 \cdot 7$ & 724 & 285 & 28 \\
\hline & & Minimum & $9 \cdot 2$ & $4 \cdot 4$ & 331 & 76 & 4 \\
\hline & & Maximum & $43 \cdot 4$ & $73 \cdot 8$ & 1367 & 833 & 75 \\
\hline \multirow[t]{3}{*}{$\mathrm{C}$} & 5 & Average & $19 \cdot 4$ & $15 \cdot 8$ & 558 & 251 & 37 \\
\hline & & Minimum & $10 \cdot 6$ & 6.0 & 334 & 153 & 4 \\
\hline & & Maximum & $29 \cdot 1$ & $35 \cdot 0$ & 907 & 484 & 80 \\
\hline
\end{tabular}

In category A canteens a choice of dishes was not provided, whereas in category B canteens a little ingenuity was used and a greater proportion vos. 3, 1945] 
of made up dishes was served. In category $\mathrm{C}$ canteens made up dishes were the general rule. These and meatless dishos compensated to a certain extent for the smaller allowances to the lower category canteens. A mobile laboratory was equipped for the estimation of vitamin $\mathrm{C}$ and figures showing the vitamin $\mathrm{C}$ content of cooked vegetables are given in Table 2.

TABLE 2

The Vitamin C Content of Cooked Vegemables Served in Industrial Canteens (mg. per $100 \mathrm{~g}$.)

\begin{tabular}{|c|c|c|c|c|c|c|c|c|}
\hline \multirow[b]{2}{*}{ Month } & & \multicolumn{4}{|c|}{ Potatoes } & \multirow[t]{2}{*}{ Cabbage } & \multirow[t]{2}{*}{ Sprouts } & \multirow[t]{2}{*}{ Swedes } \\
\hline & & boiled & mashed & roast & chips & & & \\
\hline June $\ldots$ & . & $7 \cdot 4$ & $3 \cdot 6$ & $9 \cdot 3$ & $11 \cdot 6$ & $21 \cdot 8$ & - & -... \\
\hline July $\quad$. & . & $\begin{array}{r}5 \cdot 0^{1} \\
15.5^{2}\end{array}$ & - & $10 \cdot 7$ & 23.9 & $17 \cdot 7$ & - & - \\
\hline August & . & $14 \cdot 6$ & $11 \cdot 5$ & - & - & $12 \cdot 4$ & - & - \\
\hline September & . & 11.7 & $7 \cdot 3$ & $20 \cdot 9$ & $15 \cdot 2$ & $11 \cdot 8$ & - & $14 \cdot 5$ \\
\hline October & .. & $13 \cdot 4$ & 8.9 & $18 \cdot 8$ & 21.9 & $20 \cdot 6$ & - & $14 \cdot 7$ \\
\hline Novernber & . & $9 \cdot 4$ & $3 \cdot 9$ & $14 \cdot 3$ & $16 \cdot 6$ & $8 \cdot 6$ & $44 \cdot 6$ & $10 \cdot 5$ \\
\hline December & .. & $6 \cdot 6$ & $4 \cdot 9$ & - & $13 \cdot 6$ & $11 \cdot 4$ & - & - \\
\hline January & . & $7 \cdot 7$ & $5 \cdot 4$ & $10 \cdot 9$ & - & $18 \cdot 8$ & $42 \cdot 8$ & $14 \cdot 3$ \\
\hline February & . & $6 \cdot 8$ & $4 \cdot 5$ & $6 \cdot 1$ & $7 \cdot 5$ & $6 \cdot 9$ & $18 \cdot 1$ & - \\
\hline March . & $\cdots$ & $5 \cdot 6$ & $4 \cdot 3$ & $9 \cdot 9$ & $10 \cdot 7$ & $14 \cdot 0$ & 20 & $10 \cdot 2$ \\
\hline April . . & . & $7 \cdot 6$ & $3 \cdot 8$ & $7 \cdot 9$ & $13 \cdot 8$ & $46 \cdot 6$ & 一 & $7 \cdot 0$ \\
\hline
\end{tabular}

${ }^{1}$ Old potatoes. ${ }^{2}$ New potatoes. ${ }^{3}$ Spring cabbage.

Dr. G. Graham (St. Bartholomew's Hospital, London, E.C.1): I would not like the Society to think that there has been no evidence of lack of vitamin C. I myself have seen no less than 7 cases of frank scurvy in the years 1941-43, but $I$ have not seen any this year. It is truo that most of these belonged to the type called "bachelor's scurvy", i.e., people living alone and doing their own cooking, but 2 were young men, one a soldier who disliked vegetables and the other a boy of 18 years whose mother was dead and whose father did the cooking. One man, owing to the blitz, was getting all his food in canteens.

I examined also my students at hospital in their last year, and in 1943 found that about a third of them showed well marked hyperkeratosis of the hair follicles on the backs of the thighs. This is the earliest sign of lack of vitamin C. I was particularly interested to find that the students who did their own cooking had learnt the new way of cooking vegetables and none of them showed any evidence of lack of vitamin C.

Professor Wormald has been examining students at Cambridge, using Dr. Harris's method, and has found that as each year goes by the students are less and less saturated with ascorbie acid. He will report this in full fairly soon.

The possibility that operation wounds may fail to heal should be remembered and this is especially important after operations on the stomach since peritonitis may occur. In some of such cases the adrenal glands at autopsy did not contain any ascorbic acid. I am sure, 
therefore, that the possibility of a lack of vitamin $\mathrm{C}$ should be kept always in mind.

Professor J. R. Marrack (London Hospital, Whitechapel, London, E.1): Dr. Pyke brought out the remarkable point of the small breakfasts and very large evening meals eaten by industrial workers. I do not know how to account for this, but they eat extremely little of their bacon ration. It is questionable whether they divide up their meals satisfactorily.

It may be difficult to provide more frequent meals in hospitals because, as a general rule, not more than 2000 Calories are taken. It is not possible to fit that amount into 4 meals. It is interesting to look back on a report of 45 years ago on convicts serving terms of 3 or more years' imprisonment in Peterhead gaol; they received no food that supplied vitamin A or carotene (Prison Commission for Scotland, 1899). Dr. Pyke mentioned the problem of night shifts. When people go on night shifts, they find it difficult to consume adequate amounts of food at unaccustomed hours, and the amount of bread and potatoes eaten drops immediately. How long do they take to get used to night shifts, and do they ever do so? Some factories change their workers about so frequently that they never get used to anything.

Striking results have been obtained with large doses of ascorbic acid after the extraction of teeth (Campbell and Cook, 1945). There ought to be a wider investigation.

\section{REFERENCES}

Campbell, H. G. and Cook, R. P. (1945). Proc. Nutr. Soc. 3, 89.

Prison Commission for Scotland (1899). Report on Prison Dietaries. [c. 9514]. London: H.M.S.O.

Miss M. Andross (College of Domestic Science, Park Drive, Glasgow): We have just completed a survey of the diet of women munition workers in the West of Scotland engaged on a certain process. The cramped position necessary for the work made the 3 course midday meal too heavy and only 3 per cent. of the women took it. The vitamin $\mathrm{C}$ intake averaged $25 \mathrm{mg}$. daily, derived almost entirely from potatoes; no other vegetables were eaten. Night shift workers ate fewer calories than day workers. The shifts were changed every week and there was no time for adjustment. Workers were too tired in the morning to prepare and eat a meal. In a survey of this sort the day off work should always be included to allow for the large quantities of food eaten on that day. The efficiency of workers, as judged by the works manager, corresponded to some extent with their riboflavin intake per 100 Calories.

Miss E. M. Langley replied:

To Miss Broatch: The importance of allowing children sufficient time to eat has not been overlooked, and it is common practice throughout, England and Wales for children to spend about half an hour in the dining hall. The London County Council has a difficult problem through the limitation of accommodation caused by the destruction by enemy action of many of the school buildings; hence the reason for hurried. meals. When considering the time spent over the school meals it must be remembered that the supervision is entirely voluntary. Consideration has been given to the service of a meal of the Oslo type, but in war time voc. 3,1945$]$ 
this is not practicable because of the shortage of cheese. Furthermore, the Oslo meal would not be attractive to children unless it included an orange.

In setting the standard at 1000 Calories for a meal for senior schoolchildren, the Board of Education was aiming high but, in view of the poor meals supplied in many areas prior to the war, it was important to set a good standard. Moreover, the allowances of food made available by the Ministry of Food make it possible to provide a 1000 Calorie meal, and many Local Education Authorities are working to this figure for senior school children. The meal for juniors and infants is proportionately less in food value. Some of the northern boroughs, however, claim that the senior children can eat even more than 1000 Calories if the meal is carefully balanced.

To Dr. Kerly: The food value of the meals served at school canteens is generally checked by calculation from food tables; the basis of calculation is the food issued daily and used in cooking. The analytical method would give a fairly accurate result, provided the investigator took away samples equivalent to the amount eaten by the average child. In the majority of canteens it is common for the children to have several helpings of both courses, and it is doubtful whether the second and third helpings are always taken into account when calculating.

To Dr. Magee: It is most important to remember that the midday meal is the main meal of the day for children, and those responsible for catering are aware that in that meal they must provide all the essential food constituents in case the meals supplied in the home are not adequate.

Dr. M. Pyke replied:

To Professor Marrack: The point about the consumption of small breakfasts is one of some interest. It is perfectly true that in many cases industrial workers eat little before they leave home in the morning. This is often due to the very early hour at which it is necessary for them to eat breakfast. People who begin work at about 8 o'clock need to eat their breakfast at 7 or earlier. As an extreme case, the men working on the "fore-shift" in a Durham coal mine can be cited. This shift begins at 4 a.m., so that it is necessary for the work people to eat breakfast at about 3 o'clock in the morning. While it is true that many industrial workers eat little at breakfast time, some others eat a great deal more than they themselves believe. It is not uncommon in making a survey to find that a man who says he has no breakfast, when pressed, admits grudgingly that he does indeed eat 2 or 3 slices of bread and dripping and have a cup of tea. Although this food may provide a substantial contribution of nutrients, it is dismissed lightly as not in fact constituting a meal, which, to the lay mind, implies something cooked.

To Professor Marracl and Miss Andross: Eating on the night shift is another matter of great interest and about which very little definite is known. Where a study is made of people such as miners, who work for years on a night shift and are completely acclimatized, it is found almost certain that they eat as much at night as others eat by day, but people who change shift weekly or fortnightly often suffer nutritionally. This holds particularly strongly in the case of women. I had the opportunity of studying a group of women doing heavy work on the night shift in a 
railway goods yard. The results of my survey showed that these women only ate 2000 Calories, and I am convinced that this amount was less than they needed. Night work was harder on these women than it would have been on men. They were mostly strongly built, married women of middle age and, besides the arduous labour they did in the goods yard, most of them had domestic duties to attend to as well. In some cases I found they were so tired at the end of their night's work that they went straight to bed without eating.

The question of acclimatization to night work is interesting. There are many suggestive facts in a monograph by Kleitman (1939). For example, when he lived an artificial day of 20 hours in the Mammoth Caves, Kentucky, he found that, according to his temperature rhythm, he never became acclimatized, but that his companion in the experiment did. It would seem a promising field for study to test whether there are two classes of people, those who can become acclimatized to night work and those who, no matter how long they try, can never do so.

The degree or bulkiness of ind ustrial meals, while not of direct nutritional significance, is of great importance. It is true that many people doing comparatively light and sedentary work refuse to eat an industrial meal provided in a canteen because its weight and bulk tend to make them uncomfortable and sleepy during their afternoon's work. Even for heavy workers who work on their feet, considerable study is needed as to the bulk which is suitable. An experiment was carried out with coalminers who, by the nature of their work, cannot normally eat a hot cooked meal in the middle of their shift. The experiment provided that a hot meal of the conventional meat, potatoes, vegetable and pudding type, should be taken down the mine in a thermos flask, to be eaten underground. The experiment exemplified many of the practical difficulties of carrying out such work, and it was, in fact, condemned by the people responsible for the men before it had started. The conclusion is, however, by no means clear. Although it is obvious that miners working in a crouched position in a low seam cannot appropriately eat a bulky meal, there are very many. mines in which the men have full head room, and work standing up at many hard jobs, and there is no clear a priori reason why they should not in these circumstances eat a hot dinner. The matter is, however, still badly in need of proper scientific study.

\section{REFERENCE}

Kleitman, N. (1939). Sleep and Wakefulness. Chicago: University Press.

Dr. A. Lyall replied: I would like to say that I was speaking of hospitals as they are at the moment and not as they might be in the millennium. Much as we should all like to see the best possible diets supplied in hospitals we have hospital boards and local authorities to convert.

I did not advocate that extras should be brought into hospitals by patients' friends. As a matter of fact we stopped that by making the donors deliver this food to the sister in charge. Hospitals are committed to making the diet adequate without additional food being brought in.

Things have certainly changed for the better in Peterhead prison since the time Professor Marrack referred to, for the one impression I took away was of seeing enormous baths full of vegetables.

voL. 3,1945$]$ 


\section{General Discussion}

Sir Joseph Barcroft (Physiological Laboratory, Cambridge): The point which I wish to bring out is very brief; I want to take up the parting shot with which Professor Mottram left us. His remark, made 40 per cent. in joke and 60 per cent. in earnest, left me under the impression that, for lack of a calorimeter and someone to work it, there was a hold up of really basic information in this country. I am not an authority on the borderline between calorimetry and other methods of estimating energy use of foods, but I do think that it is a very serious matter if that 60 per cent. of what Professor Mottram said is substantiated and that those who are carrying out such wonderful work by other methods are overworked for want of the opportunity to apply this method. Therefore, I propose the following motion:

"That the Committee be requested to investigate the alleged necessity for the conduct of ealorimetric investigations in this country and, if satisfied of the necessity, to investigate further the possibility of carrying out such research".

Even though the calorimeter is a special instrument, I cannot think that with the authority of this Society behind it, the Committee could not get both the money and the workers.

Dr. E. R. Bransby (Ministry of Health, Whitehall, London, S.W.1): It is of interest to mention an original and valuable paper recently published, in which an attempt was made to relate calorie intake to calorie expenditure (Wiehl, 1944). Diet histories and records of daily activity were obtained for about 300 pupils in a private high school and for 2000 pupils in a public high school in New York. Calorie expenditure was calculated for each child from basal energy requirements according to age and surface area and from the length of time during the day spent on sedentary, light, moderate and severe activity. Adjust. ments were made for reduced energy expenditure during sleep, for digestive waste and for growth. There was considerable variation in calculated energy expenditure; thus for 28 boys aged 16 years the range was from 2600 to 3700 Calories daily. There was a wide range also of calorie intakes; for 35 boys aged 13 years the range was 1640 to 4895 Calories daily. Comparison was made for each pupil between calorie intake and calorie expenditure. On the average, the private school boys had an intake of 103 per cent. and the girls of 96 per cent. of expenditure. The Jewish public school boys had an intake of 82 per cent. and the girls of 86 per cent. of their requirements. Nine per cent. of the private school boys and 31 per cent. of the Jewish public school boys had an intake less than 70 per cent. of their expenditure. Comparison was made for the private school boys between the weight status aceording to the Wood Baldwin standard scale and the percentage of calorie expenditure represented by calorie consumption. There was no positive correlation between these 2 values; in fact, diets furnishing less than 70 per cent. of expenditure were more prevalent among overweight, than underweight, pupils, and high calorie diets were more prevalent among underweight pupils. The author stresses that the magnitude of the difference between individual requirements shows clearly that average values for requirement 
are unsuitable for evaluation of the adequacy of individual calorie intake. This paper supports the opinion already expressed at this meeting that there is still much work to be done on calorie requirements which should not be limited to measurement of basal metabolism, but should include also a study of the calorie needs for activity and growth.

REFERENCE

Wiehl, D. G. (1944). Milbank Mem. Fd Quart. 22, 5.

Dr. E. M. Widdowson (Department of Medicine, Cambridge): I would like to second Sir Joseph Barcroft's motion. I do feel that the good old fashioned calories are getting overlooked because of the tremendous modern enthusiasm for vitamin $\mathrm{C}$.

Dr. J. Hammond (School of Agriculture, Cambridge): Is it the wish of this meeting that, as Chairman, I should ask the Committee of the English Group to deal with the matter raised by Sir Joseph Barcroft?

(Those present were unanimously in favour of the Committee being so asked.)

\section{Summing up by Professor L. A. Maynard}

Professor L. A. Maynard (School of Nutrition, Cornell Unive rsity, Ithaca, N.Y., U.S.A.): I think the Society's method of conducting the programme is an excellent one by which, at the end, a summary is given of the ideas presented. I much appreciate having been asked to do this.

You have been discussing the problem of determining nutritional status and requirements, and some differences of opinion have appeared. These differences are of a type which can become tiresome when an attempt is made to arrive at a common basis for comparisons between different countries. Dr. Platt referred to the nutritional allowances cited at the Hot Springs Conference. They afforded an example in which the differences had significance particularly in terms of the methods used in evaluating food supply, an aspect which is sometimes not remembered. For instance, when the study was made last summer for Food Consumption Levels (Special Joint Committee Set up by the Combined Food Board, 1944), a difference of about 5 per cent. was found between the results for the different countries in arithmetical calculation of calories.

Another important divergence occurred in connexion with the calculation of the vitamin A requirement. The value of 5000 I.U. which the U.S.A. takes for the requirement is frequently referred to as too high, but it is not always understood how that value was reached. It was considered to be made up of 3000 I.U. as carotene and 2000 I.U. as vitamin A. There is the further problem of the value of the carotenes in terms of vitamin A. I attended a meeting in Sheffield of the team conducting a human experiment there on vitamin A. I anticipate that valuable results will come out of that experiment.

I am impressed by the fact that it is possible to do a job reasonably well by different procedures each of which works out all right for a given country, but that, when we try to put the results together, it becomes too difficult because the procedures used were different. It is most important that we should try to find common ground though, when serving vor. 3,1945$]$ 
our own country, we may not feel that there is any special need for this. When, however, we are trying to co-operate with other countries we must try to resolve these differences which arise from not using the same methods of biological estimation and so on. I do not think the differences are really as large as we think; they are due more to the way we express things.

To the United Kingdom and the U.S.A. will fall the biggest part of the task in making a wide assessment of nutritional needs and in allotting the foodstuffs from many different countries, so that it is vital for us to have a common basis according to which foodstuffs can be supplied by one country to another. We shall have to make adjustments in order to harmonize the whole.

One difficulty is that the nutrition expert and the biochemist deal with the same data but they speak in different languages. We can make things very much more satisfactory if we get together and become quite sure that we are talking about the same things so that, for instance, Lease Lond food does not appear to change in value as it crosses the ocean; we have here a real reason for trying to resolve these differences. Probably the most fundamental reason for such differences is a lack of scientific knowledge, and what we need is more physiological experiments to bring the facts to light. I am convinced that some of the problems can be solved only in this way.

\section{REFERENOE}

Special Joint Committee Set up by the Combined Food Board (1944). Food Consumption Levels in the United States, Canada and the United Kingdom. London: H.M.S.O. 